\title{
Modeling soil organic carbon in corn (Zea mays L.)-based systems in Ohio under climate change
}

\author{
E.D.v.L. Maas, R. Lal, K. Coleman, A. Montenegro, and W.A. Dick
}

\begin{abstract}
Soil organic carbon (SOC) is a key indicator of soil quality. Knowledge of the effects of land management and climate change on SOC stocks is of vital importance in creating future sustainable land use systems. This study presents both the promise and current challenges of modeling SOC in mineral soils under climate change. Soils data from two longterm agricultural research sites in Ohio under no-till (NT) and plow-till (PT) management, the RothC soil $\mathrm{C}$ model, and climate data from the Canadian Regional Climate Model were used to project future SOC content in agricultural soils using low-emissions (LE) and high-emissions (HE) climate change scenarios. It was hypothesized that from 2015 to 2070 , SOC levels in soils under NT management in Ohio will show increasing trends under the LE scenario, decreasing trends in NT under the HE scenario, and decreasing trends in PT under both scenarios, with lower levels of SOC for both treatments under the HE scenario. The results of this study projected total SOC content in the topsoil layers $(0$ to $25 \mathrm{~cm}[0$ to $10 \mathrm{in}$ ] at Wooster and 0 to $23 \mathrm{~cm}$ [0 to $9 \mathrm{in}$ ] at Hoytville) to decrease at all sites and under all management and climate projections, with the exception of NT at Wooster and Hoytville and PT at Wooster under the LE scenario. Starting at $32.4 \mathrm{Mg} \mathrm{C} \mathrm{ha}^{-1}\left(14.5 \mathrm{tn} \mathrm{C} \mathrm{ac}^{-1}\right)$ in 1962 at Wooster, by 2070, soil under NT management is projected to have 45.4 and $32.1 \mathrm{Mg} \mathrm{C}$ $\mathrm{ha}^{-1}$ (20.3 and $14.3 \mathrm{tn} \mathrm{C} \mathrm{ac}{ }^{-1}$ ) for LE and HE scenarios, respectively, while PT management starting at $31.5 \mathrm{Mg} \mathrm{C} \mathrm{ha}^{-1}\left(14.1 \mathrm{tn} \mathrm{C} \mathrm{ac}^{-1}\right.$ ) would have 29.4 and $21 \mathrm{Mg} \mathrm{C} \mathrm{ha}^{-1}$ (13.1 and 9.4 tn $\mathrm{C} \mathrm{ac}^{-1}$ ) for LE and HE scenarios, respectively. Starting at $65.2 \mathrm{Mg} \mathrm{C} \mathrm{ha}^{-1}\left(29.1 \mathrm{tn} \mathrm{Cac}^{-1}\right)$ in 1963 at Hoytville, by 2070, soil under NT management would have 65.9 and $51 \mathrm{Mg} \mathrm{C} \mathrm{ha}^{-1}$ (29.4 and 22.8 tn $\mathrm{C} \mathrm{ac}^{-1}$ ) for LE and $\mathrm{HE}$ scenarios, respectively, and PT starting at $63.5 \mathrm{Mg}$ $\mathrm{C} \mathrm{ha}^{-1}\left(28.3 \mathrm{tn} \mathrm{C} \mathrm{ac}^{-1}\right)$ would have 36.9 and $28.7 \mathrm{Mg} \mathrm{C} \mathrm{ha}^{-1}\left(16.5\right.$ and $12.8 \mathrm{tn} \mathrm{C} \mathrm{ac}^{-1}$ ) for LE and $\mathrm{HE}$ scenarios, respectively.
\end{abstract}

Key words: agriculture—carbon sequestration—climate change-modeling-Ohio—soil organic carbon

\begin{abstract}
Soil carbon (C) sequestration is a vital process in the global $\mathrm{C}$ cycle, particularly under climate change, and computer modeling of projected C stocks is a key tool for mitigation and adaptation planning. Soil provides many ecosystem services, including a vital role in the global regulation of carbon dioxide $\left(\mathrm{CO}_{2}\right)$ and other greenhouse gases (GHG) (Hatfield et al. 2014), and is a key soil health indicator (Reeves 1997). Between 2005 and 2014, the "land sink," including soil and vegetation, sequestered $30 \%$ of $\mathrm{CO}_{2}$ emissions $(160 \pm 60 \mathrm{Gt}$ C [176 \pm 66 billion tn]), including fossil fuel burning and land use change (Le Quéré et al. 2015). Within the
\end{abstract}

$\mathrm{C}$ (SOC) and exposing more surface area to heat, moisture, and oxygen (O) (Uri 2001).

Temperature and moisture are known to facilitate acceleration of decomposition rates. Additionally, over the past two decades, it has become increasingly clear that climate change will increase both temperature and precipitation by the end of the century in many regions that are currently key to agriculture (IPCC 2013; Melillo et al. 2014). On a global scale, the likelihood of continuing temperature increases is "virtually certain" (greater than 99\% probability), and of heavy precipitation events is "very likely" by the end of the century, at least over midlatitude land masses and wet tropical regions (IPCC 2013). These predictions apply to the Midwest region of the United States (Walsh et al. 2014; Hatfield et al. 2014), one of the most important agricultural areas in the world (Hatfield et al. 2012), where the combined stresses will have adverse effects on agriculture and are expected to decrease productivity (Janetos et al. 2008; Pryor et al. 2014).

Increases in average precipitation and intensity of downpours will also increase the likelihood of water erosion. Erosion removes the upper layers of soil first, which usually contain the highest concentrations of organic matter (OM), and therefore SOC, in the soil profile (Kaurin et al.2015). Loss of OM is one important process that degrades soil (Hatfield at al. 2014). All of these factors affect the capacity of soil to sequester and hold SOC that, in turn, affects the sustainability of agriculture and humanity's ability to feed itself.

It is imperative that humanity makes rapid and decisive changes to address this global climate change threat. However, mitigation and adaptation methods must be scientifically informed. Sequestration of SOC has

Ellen D.v.L. Maas (corresponding author) is a graduate teaching assistant at the Carbon Management and Sequestration Center, School of Environment and Natural Resources, The Ohio State University, Columbus, Ohio. Rattan Lal is the director at the Carbon Management and Sequestration Center, School of Environment and Natural Resources, The Ohio State University, Columbus, Ohio. Kevin Coleman is a research scientist for Rothamsted Research, Harpenden, Hertfordshire, United Kingdom. Alvaro Montenegro is an assistant professor in the Department of Geography, The Ohio State University, Columbus, Ohio. Warren A. Dick is a professor at the School of Environment and Natural Resources, The Ohio State University, Columbus, Ohio. 
been proposed as one tool to mitigate the effects of climate change (Lal 2004a) and was an official proposal at the 21st Conference of the Parties to the United Nations (UN) Framework Convention on Climate Change (COP21), known as "4 Per Thousand." Current estimates (Lal 2016) indicate that, globally, agriculture has the physical potential to sequester $62 \mathrm{Mg} \mathrm{C}^{-1}\left(27\right.$ tn $\mathrm{C} \mathrm{ac}^{-1}$ ) over the next 50 to 75 years, with additional potential in pasture, forest, degraded, and desertified lands. Public policy would be an invaluable support in reaching this potential. However, considering that the timeframe of change of many soil physical properties exceeds the typical policy review cycle (one to five years in the United States), it is not always possible to monitor changes that occur because of policy applications (Kibblewhite et al. 2016). Monitoring is also expensive and time-consuming (Makipaa et al. 2008; Jimenez and Ladha 1993). Modeling efforts are thus being evaluated as a cost effective way to help policymakers make informed decisions about land use and management in ways that will support climate change mitigation efforts, and modeling is a key element to those efforts (Paustian et al. 2016).

Jones et al. (2005) simulated global-scale soil $\mathrm{C}$ dynamics with the Hadley Centre's coupled climate- $\mathrm{C}$ cycle general circulation model (with a simple single-pool C model) and RothC (a more complex multiple-pool C model) from 1860 through 2100. Both models calculated soil $\mathrm{C}$ increases due to increased plant $\mathrm{C}$ input from $\mathrm{CO}_{2}$ fertilization until 2000, when the global stocks of C roughly leveled off due to increased plant respiration from increasing temperature. After 2060, both models projected continually increasing plant respiration to surpass plant $\mathrm{C}$ inputs, resulting in a dramatic switch of soil as a $\mathrm{C}$ sink to a source.

While it is important to understand trends at the global scale, local action requires knowledge of local trends, and global modeling is too general for this purpose. Therefore, the next step in this evaluation is to scale projections down to the regional level with regional climate model data. To date, related agricultural studies in the literature conducted for Ohio or surrounding regions in the midwestern United States under climate change have primarily focused on crop yields (Littlefield et al. 1998; Southworth et al.2002; Panagopoulos et al. 2015). Modeling studies have evaluated historical trends in $\mathrm{C}$ dynam- ics (Evrendilek and Wali 2001; Dold et al. 2017) or developed region-predictive models (Mishra et al. 2010) without including future predictive simulations, or included future predictive simulations but with global climate model data (Pan et al. 2010; Lu and Xiaoliang 2010; Basche et al. 2016). Evrendilek and Wali (2004) projected SOC levels in Ohio under increased $\mathrm{CO}_{2}$ and temperature over 100 years, but the increased values remained constant throughout the simulation and did not include changes in precipitation.

The primary objective of this study is to project future levels of terrestrial $\mathrm{C}$ within corn (Zea mays)-based agricultural systems in Ohio under both plow-tillage (PT) and no-tillage (zero tillage; NT) management, and low-emissions (LE) and high-emissions (HE) climate change scenarios (based on varying assumptions of future global GHG emissions) using predictive monthly temperature, precipitation, and open pan evaporation data through the year 2070 produced by a regional level climate model. Only when there are better models at a local or regional level can scaling up to a larger level landscape provide really useful results.

There is a large body of evidence in the literature that NT management results in an increase in surface ( 0 to $20 \mathrm{~cm}$ [0 to 8 in]) SOC under many soil types and climatic conditions, though the effectiveness of NT management over PT to sequester $\mathrm{C}$ has been hotly debated (Gregorich et al. 2007; Blanco-Canqui and Lal 2008; Hammons 2009; Powlson et al. 2014; VandenBygaart 2016). The concerns have been addressed in part by two meta-analyses comparing PT to NT, where NT was found to sequester significantly more C than PT to $30 \mathrm{~cm}$ (12 in) (Angers and Eriksen-Hamel 2008) and to $160 \mathrm{~cm}$ (63 in) (Mangalassery et al. 2015).

Given that NT sequesters more C than $\mathrm{PT}$, that increases in temperature and precipitation are factors that can increase the rate of decomposition, and that increases in both by the end of the century are projected to be substantial across the Midwest, the following hypotheses were tested in this study:

- From 2015 through 2070, levels of SOC in soils under NT management in Ohio will show increasing trends under the LE scenario, decreasing trends under PT management in the LE scenario, and trends of depletion in both treatments under the HE scenario.

- Also, by 2070, levels of SOC in soils of both NT- and PT-managed sites in Ohio will be projected to decrease more under a HE than a LE climate change scenario.

\section{Materials and Methods}

Soil Carbon Model. There is a wide range of computer simulation models that includes a soil C cycle component, from global climate models to ecosystem models. Several were reviewed for consideration, including Rothamsted Carbon (RothC), Estimate Carbon in Organic Soils - Sequestration and Emissions, Century, DayCent, DeNitrification-DeComposition, and Environmental Policy Integrated Climate. We chose the RothC model, standard version (26.3), for its ease of use, easily obtainable inputs, usability for most soil types, and high counts of published studies that have used RothC for a purpose similar to this study, which lends credibility to its output. It was developed to model the turnover of SOC in nonwaterlogged topsoils, and runs on a monthly timestep (Coleman and Jenkinson 2014). A model with a smaller timestep was not deemed necessary for this study due to the nature of SOC to change slowly over time, and the exclusion of $\mathrm{N}$, which would require a smaller timestep.

RothC considers the following four active $\mathrm{C}$ pools with their own first-order decay rates (given for $9.25^{\circ} \mathrm{C}\left[48.7^{\circ} \mathrm{F}\right]$ ): (1) decomposable plant material (DPM) at $10 \mathrm{mo}^{-1},(2)$ resistant plant material (RPM) at $0.3 \mathrm{mo}^{-1}$, (3) microbial biomass (BIO) at $0.66 \mathrm{mo}^{-1}$, and (4) humified organic matter (HUM) at $0.02 \mathrm{mo}^{-1}$ (Jones et al. 2005). Each rate is modified as a function, $\mathrm{F}$, of monthly mean surface air temperature $\left(\mathrm{T}_{\mathrm{a}}\right)$ :

$$
F=\frac{47.91}{1+\mathrm{e}^{\left(\frac{106.06}{T_{a}+18.27}\right)}}
$$

The rate of decomposition is also calculated from soil clay content, the presence or absence of vegetation, and the soil moisture deficit (calculated as the difference between total monthly precipitation and open pan evaporation) (Jones et al. 2005).

Kinetic theory is a useful framework to evaluate the response of decomposition to temperature change (Conant et al. 2011) and how RothC follows these principles. RothC accounts for the first component of kinetic theory in that the decomposition rate increases with an increase in temperature. The second component states that the rate of change in 
decomposition should be the maximum at lower temperatures. In RothC, however, the rate of change of decomposition rates rises until about $26^{\circ} \mathrm{C}\left(79^{\circ} \mathrm{F}\right)$, when the rate of change begins to decrease. The third component of kinetic theory (and the topic of the greatest debate [Conant et al. 2011]) implies that decomposition reactions of slow-pool $\mathrm{OM}$ will increase more proportionally than fast-pool OM; in RothC, the same temperature modifying factor is applied to all pools.

Historical Weather Data. To fit RothC to observed SOC levels, weather measurements are needed over the course of the agricultural experiments for monthly mean air temperature, rainfall, and open pan evaporation. Therefore, Annual Climatological Summary data were downloaded from the National Climatic Data Center for the Wooster and Hoytville weather stations corresponding with the agricultural plots used for this study (Menne et al. 2012a, 2012b). Missing open pan evaporation data were calculated using Thornthwaite and Mather's (1955) calculation for potential evapotranspiration.

Regional Climate Model. Climate predictions can be used in conjunction with the RothC model to generate estimates of future SOC levels. Ideally, predictive climate data for the local proximity of each agricultural experiment site would provide the most relevant data for modeling SOC levels at each individual site. However, robust point estimates of future climate are not available at this high level of resolution. Global circulation models (GCM) could be helpful, but are too low resolution for use at a specific site (Mearns et al. 2013). A regional climate model (RCM) is the best compromise currently available.

The North American Regional Climate Change Assessment Program (NARCCAP) provides a suite of RCMs. Each model exhibits biases, so the model selected should exhibit the least bias within the factors of interest over the applicable region, in this case temperature and precipitation over Ohio. A careful qualitative analysis of graphical output from each RCM was performed, comparing the observational climate data (limited to 1979 through 2003) from the University of Delaware's Center for Climatic Research to the output from each RCM's attempts to reconstruct them. This qualitative analysis consisted of the following four categories: (1) winter temperature, (2) winter precipitation, (3) summer temperature, and (4) summer precipitation; and three spatial scales: (1) national (United States), (2) regional (Midwest), and (3) state (Ohio) Based on this somewhat subjective analysis, the Canadian Regional Climate Model (CRCM) was selected as the best available fit. Over Ohio, it replicated winter temperatures $\pm 2{ }^{\circ} \mathrm{C}\left( \pm 3.6^{\circ} \mathrm{F}\right)$, winter precipitation from $0 \%$ to $50 \%$ increases, summer temperatures $-2^{\circ} \mathrm{C}\left(-3.6^{\circ} \mathrm{F}\right)$ to $+4^{\circ} \mathrm{C}\left(+7.2^{\circ} \mathrm{F}\right)$, and summer precipitation from $-10 \%$ to $+50 \%$ differences (NARCCAP 2016a). Furthermore, to produce the future climate projection data, each RCM is paired with a GCM, which provides data for the boundary conditions of each region. The RCM then uses higher-resolution data for factors such as topography, convective precipitation, and local-scale soil moisture to produce the projections within the given region. The future climate data chosen for this study from the CRCM were produced as paired with the Third Generation Coupled Global Climate Model (CGCM3), version 3.1 (NARCCAP 2016c; Mearns et al. 2007). This GCM was used to produce the emissions scenarios for the IPCC's Fourth Assessment Report (ECCC 2016). The climate data projected by the CRCM-CGCM3 pairing are among the least variable over the Bukovsky regions relevant to this study (Appalachia [Wooster] and Great Lakes [Hoytville]) (Bukovsky 2011; NARCCAP 2016d).

The original goal of this study was to run projections to the year 2100 from the regional model with simulations equivalent to the IPCC's global RCP2.6 and RCP8.5 GHG emissions scenarios. (RCP2.6 represents a scenario where global temperature rise is kept below $2^{\circ} \mathrm{C}\left[3.6^{\circ} \mathrm{F}\right]$ over preindustrial temperatures with an aggressive reduction in global annual GHG emissions to 0 by 2100 , while RCP8.5 represents a conversely aggressive rise in GHG emissions topping out at just over $100 \mathrm{Gt} \mathrm{CO}_{2} \mathrm{y}^{-1}[110$ billion $\mathrm{tn}^{\mathrm{yr}^{-1}}$ ] by 2100 [IPCC 2014].) Several factors prevented this goal. At the time of our analysis, only a business-as-usual HE scenario was available from the NARCCAP program, equivalent to the former IPCC A2 scenario (NARCCAP 2016b). The IPCC's A2 scenario represents slightly lower emissions than RCP8.5 (Cubasch et al. 2013). Additionally, the date range of future climate data from the RCMs was limited to 2038 through 2070.

In lieu of a LE scenario from the NARCCAP regional models, a LE scenario was simulated using the 31-year average temperature, precipitation, and open pan evaporation data from the National Oceanic and Atmospheric Administration (NOAA) observed weather data set from 1985 through 2015. This represents the best-case (albeit unrealistic) scenario of no further climate change and serves as a baseline comparison.

Agricultural Sites. Detectable changes in SOC only occur over many years, therefore only long-term agricultural projects that consistently tracked changes in $\mathrm{C}$ would yield meaningful results. This study utilizes data collected from the Triplett-Van Doren experimental plots, located near the cities of Wooster and Hoytville in Ohio. They have been run by the Ohio Agricultural Research and Development Center (OARDC) of The Ohio State University since 1962 and 1963, respectively, through 2010. From 2011 to 2015 they came under the coordination of the Cropping Systems Coordinated Agricultural Project (CSCAP 2016). These two sites include the world's longest-running NT research plots to date. The Hoytville site has had little change in its treatments since inception, and the Wooster site also had little change in its treatments through 2006 (Dick et al. 2013). Additional details about the site, sampling, and analysis not included in this paper are available in prior publications (Dick et al.1986a, 1986b, 2013; Kladivko et al.2014).

The USDA defines Major Land Resource Areas (MLRA) to identify regions with similar characteristics, such as soil, climate, and land use (USDA NRCS 2005). Hoytville is included in the $28,370 \mathrm{~km}^{2}\left(10,950 \mathrm{mi}^{2}\right)$ Erie-Huron Lake Plain MLRA, 59\% of which is cropped, and which includes parts of Michigan, Indiana, and Ohio (USDA NRCS 2006a). The Hoytville site's soil is classified as a silty clay loam and poorly drained with a slope of $<1 \%$ (Dick et al. 1986b). Drainage tiles were installed in 1952, which predates the experimental period.

Wooster is included in the $27,770 \mathrm{~km}^{2}$ $\left(10,715 \mathrm{mi}^{2}\right)$ Lake Erie Glaciated Plateau MLRA, 29\% of which is cropped, and which includes parts of Ohio, Pennsylvania, and New York (USDA NRCS 2006b). The Wooster site's soil is classified as a silty loam. It is deep, well drained, and moderately permeable (Dick et al. 1986a), with a slope varying from $2.5 \%$ to $4 \%$ (Dick 1983) with no mention of drainage tiles. Due to extensive erosion in the Wooster PT plots, they were releveled with added topsoil in 2006 to 
equate the elevation of the NT plots, effectively ending the PT trial for this study.

Tillage systems at both sites include NT, $\mathrm{PT}$, and minimum tillage. For this study, only NT and PT were compared. Tillage and crop rotation management has been parallel between the Hoytville and Wooster sites and continuously maintained since their beginnings, with only minor modifications over time. The three crop rotations are (1) continuous corn, (2) corn and soybeans (Glycine max L.) in a two-year rotation, and (3) corn, oat (Avena sativa) or hay, and hay in a three-year rotation (Dick et al. 2013). This study averaged soil data across all crop rotations each for NT and PT treatment as an opportunity to generalize results over some of the most common rotations used in the Midwest, providing a broader application of these results of this study. Both sites are rainfed with no irrigation.

Soil data usable for this study were collected about every six to seven years. Samples collected during the experiment were taken in the fall of the year after harvest. For both sites, the baseline year data are from soil survey results taken in the proximity of the plots, but not directly from the plots. At Wooster, the 1962 baseline data set is from a site within $250 \mathrm{~m}$ (273 yd) away (Dick et al. 1986a); at Hoytville, the 1963 baseline data set was from a soil survey sample within 1 km (0.6 mi) away (Dick et al. 1986b). This presents a problem for SOC modeling, which will be discussed later.

Soil samples were taken to varying depths in varying increments over the years. The data within each treatment in each site were therefore averaged to the depth chosen for each site. For Wooster (table 1), the depth chosen was 0 to $25 \mathrm{~cm}$ (0 to 10 in). For Hoytville (table 2), the depth chosen was 0 to $23 \mathrm{~cm}$ (0 to 9 in). These depths correspond with the complete topsoil layer at each site. RothC processing is valid to any depth provided it is classified as topsoil (normally 15 to $30 \mathrm{~cm}$ [5.9 to $11.8 \mathrm{in}]$ ). Since the main purpose of this study is to compare the NT and PT treatments within each site to each other, the small difference in depths between sites is not critical.

The following calculations were used, where measurements were not made directly:

$\mathrm{OC} \%=\frac{\mathrm{OM} \%}{1.72}($ Combs and Nathan 1998),

Table 1

Data collected for the Wooster site. Each value represents either a single sample or an average of multiple samples collected in each given year. Plow-till data from 2011 to 2015 were excluded from the study due to site changes after 2005. SOC = soil organic carbon; FD-TOC = total organic carbon calculated to a fixed depth; ESM-TOC = total organic carbon calculated to an equivalent soil mass.

\begin{tabular}{|c|c|c|c|c|c|c|c|}
\hline Year & $\begin{array}{l}\text { Depth } \\
\text { (cm) }\end{array}$ & Treatment & $\begin{array}{l}\text { Bulk } \\
\text { density } \\
\left(\mathrm{Mg} \mathrm{m}^{-3}\right)\end{array}$ & $\begin{array}{l}\text { soc } \\
(\%)\end{array}$ & $\begin{array}{l}\text { Clay } \\
(\%)\end{array}$ & $\begin{array}{l}\text { FD-TOC } \\
\left(\mathrm{Mg} \mathrm{C} \mathrm{ha-1)}^{-1}\right.\end{array}$ & $\begin{array}{l}\text { ESM-TOC } \\
\left(\mathrm{Mg} \mathrm{C} \mathrm{ha}^{-1}\right)\end{array}$ \\
\hline 1962 & 25 & Baseline & 1.25 & $1.02 \dagger$ & 16.5 & 31.9 & 31.9 \\
\hline 1971 & 25 & No-till & 1.39 & 1.37 & - & 47.6 & 42.7 \\
\hline 1979 & 25 & No-till & $1.39 *$ & 1.24 & - & 43.4 & 38.8 \\
\hline 1980 & 25 & No-till & 1.40 * & 1.21 & - & 42.1 & 37.6 \\
\hline 1993 & 25 & No-till & 1.36 & 1.30 & 23.7 & 44.3 & 40.5 \\
\hline 2003 & 25 & No-till & 1.37 & 1.23 & - & 42.2 & 38.2 \\
\hline 2005 & 25 & No-till & 1.53 & $1.69 \ddagger$ & 14.8 & 64.6 & 52.6 \\
\hline 2011 & 25 & No-till & 1.46 & 1.58 & - & 57.6 & 49.2 \\
\hline 2013 & 25 & No-till & $1.43 *$ & 1.21 & 21.8 & 43.4 & 37.7 \\
\hline 2015 & 25 & No-till & 1.37 & 1.34 & - & 46.0 & 41.7 \\
\hline 1971 & 25 & Plow-till & 1.39 & 1.24 & - & 43.0 & 38.6 \\
\hline 1979 & 25 & Plow-till & $1.40 *$ & 1.05 & - & 36.6 & 32.7 \\
\hline 1980 & 25 & Plow-till & $1.40 *$ & 1.03 & - & 35.9 & 31.9 \\
\hline 1993 & 25 & Plow-till & 1.38 & 0.95 & 24.8 & 32.6 & 29.5 \\
\hline 2003 & 25 & Plow-till & 1.47 & 0.93 & - & 34.2 & 29.0 \\
\hline 2005 & 25 & Plow-till & 1.66 & $1.12 \ddagger$ & 14.2 & 46.2 & 34.8 \\
\hline $2011 \S$ & 25 & Plow-till & 1.40 & 1.35 & - & 47.4 & 42.1 \\
\hline $2013 \S$ & 25 & Plow-till & $1.59 *$ & 1.34 & 20.9 & 53.2 & 41.7 \\
\hline $2015 \S$ & 25 & Plow-till & 1.41 & 1.40 & - & 49.4 & 43.7 \\
\hline
\end{tabular}

*Indicates missing data for the sample year. Values were estimated by regression. †SOC (\%) calculated as OM (\%) $\div 1.72$.

ҒTC (\%) measured this year. SOC (\%) assumed to equal TC (\%) due to low pH values $(<6.2 \mathrm{pH})$. $\S$ Data excluded from study due to post-2006 site changes.

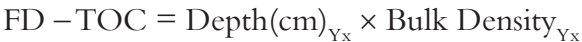
$\times \mathrm{OC}_{\mathrm{Yx}} \%$

where FD-TOC is total organic C to a fixed depth and the "Yx" subscript refers to each subsequent year sampled, and

$\mathrm{ESM}-\mathrm{TOC}=\operatorname{Depth}(\mathrm{cm})_{\mathrm{Y} 0} \times$ Bulk Density $_{\mathrm{Y} 0} \times \mathrm{OC}_{\mathrm{Yx}} \%$,

where ESM-TOC is total organic C in equivalent soil mass and the "Y0" subscript refers to the values from the baseline year. The equivalent soil mass equation (ESMTOC) was adapted from Lee et al. (2009).

Not all data were collected in each sampling year, so missing data applicable to this study were averaged or estimated. Clay content measurements varied considerably between years within each site and treatment. Because this attribute requires timeframes longer than the experimental period to change significantly, the average percentage content was calculated for each site (Wooster
$=19.1 \%$ and Hoytville $=42.8 \%$ ) from the values that were collected, in order to use a consistent value with RothC throughout the experimental period. These values are well within the described soil textures (USDA NRCS 2016) of each site.

SOC percentage was measured each year with the exception of 2005 when the total C (TC) percentage was measured instead. Due to the consistently low $\mathrm{pH}$ values measured in 2005 , the SOC percentage was simply set equal to the TC percentage (tables 1 and 2). Overall, $\mathrm{pH}$ values at Wooster ranged from 4.6 to 7.2 (median 6.1) and 4.6 to 7.3 (median 6.1) at NT and PT sites, respectively, and at Hoytville from 5.5 to 7.4 (median 6.8) and 6 to 7.2 (median 6.9) at NT and PT sites, respectively.

Missing bulk density values were estimated. An acceptable pedo-transfer function was not available, so existing bulk density data collected from each site and treatment were plotted and values for the missing years were calculated from the trend line equation. However, difficulties arose when consider- 


\section{Table 2}

Data collected for the Hoytville site. Each value represents either a single sample or an average of multiple samples collected in each given year. $\mathrm{SOC}=$ soil organic carbon; FD-TOC $=$ total organic carbon calculated to a fixed depth; ESM-TOC $=$ total organic carbon calculated to an equivalent soil mass.

\begin{tabular}{|c|c|c|c|c|c|c|c|}
\hline Year & $\begin{array}{l}\text { Depth } \\
\text { (cm) }\end{array}$ & Treatment & $\begin{array}{l}\text { Bulk } \\
\text { density } \\
\left(\mathrm{Mg} \mathrm{m}^{-3}\right)\end{array}$ & $\begin{array}{l}\text { SOC } \\
(\%)\end{array}$ & $\begin{array}{l}\text { Clay } \\
(\%)\end{array}$ & $\begin{array}{l}\text { FD-TOC } \\
\left(\mathrm{Mg} \mathrm{C} \mathrm{ha}^{-1}\right)\end{array}$ & $\begin{array}{l}\text { ESM-TOC } \\
\left(\mathrm{Mg} \mathrm{C} \mathrm{ha-1}^{-1}\right)\end{array}$ \\
\hline 1963 & 23 & Baseline & 1.30 & $3.31 \dagger$ & 37.0 & 99.1 & 99.1 \\
\hline 1978 & 23 & No-till & $1.36 *$ & 2.31 & - & 72.0 & 69.1 \\
\hline 1980 & 23 & No-till & $1.35 *$ & 2.77 & - & 70.7 & 67.9 \\
\hline 1993 & 23 & No-till & 1.35 & 2.63 & 48.9 & 81.5 & 78.7 \\
\hline 1996 & 23 & No-till & 1.39 & 2.32 & - & 73.9 & 69.3 \\
\hline 2005 & 23 & No-till & 1.25 & $2.44 \ddagger$ & 34.8 & 69.8 & 72.8 \\
\hline 2011 & 23 & No-till & 1.31 & 1.83 & - & 55.2 & 54.8 \\
\hline 2013 & 23 & No-till & $1.33 *$ & 1.76 & 48.1 & 53.7 & 52.6 \\
\hline 2015 & 23 & No-till & 1.38 & 2.28 & - & 72.6 & 68.2 \\
\hline 1978 & 23 & Plow-till & 1.27 * & 1.99 & - & 57.9 & 59.4 \\
\hline 1980 & 23 & Plow-till & 1.27 * & 2.00 & - & 58.5 & 59.7 \\
\hline 1993 & 23 & Plow-till & 1.36 & 1.95 & 50.2 & 61.1 & 61.1 \\
\hline 1996 & 23 & Plow-till & 1.25 & 1.69 & - & 48.5 & 50.5 \\
\hline 2005 & 23 & Plow-till & 1.42 & $1.81 \neq$ & 36.8 & 59.0 & 54.1 \\
\hline 2011 & 23 & Plow-till & 1.37 & 1.56 & - & 49.3 & 46.6 \\
\hline 2013 & 23 & Plow-till & $1.39 *$ & 1.56 & 49.5 & 49.8 & 46.7 \\
\hline 2015 & 23 & Plow-till & 1.38 & 1.66 & - & 52.5 & 49.5 \\
\hline
\end{tabular}

*Indicates missing data for the sample year. Values were estimated by regression.

†SOC (\%) calculated as OM (\%) $\div 1.72$.

$\ddagger$ TC (\%) measured this year. SOC (\%) assumed to equal TC (\%) due to low pH values ( $\leq 6.5 \mathrm{pH})$.

ing the anomalies noted earlier in this paper regarding the initial soil samples in the starting years, as well as the site adjustment to the PT plots at Wooster in 2006. Therefore, the trend line equations chosen for the bulk density estimates were taken from those that represented just the data taken from the sites during the experimental period, excluding post-2006 data for the PT site at Wooster (see figure 1 for Wooster and figure 2 for Hoytville), and baseline year data at both sites.

As evident in tables 1 and 2 and figures 1 and 2 , the bulk densities increased over time for PT treatments at both sites and for NT at Wooster. This can present a problem in calculating TOC, as the total mass of soil sampled over time increases as compaction occurs (Lee et al. 2009). To account for this change, the equivalent soil mass was calculated.

Modeling Run Setup. The modeling run for this study with RothC involves three steps: (1) establishing actual or average observed historical values, (2) a best-fit run to align the model with the observed values, and (3) a projection run to model future estimates. It is essential to fit the model to observed historical measurements first to ensure that the model is mimicking the site-specific param- eters correctly. Once the model can closely reproduce the observational data, then it can be run forward with expected future values on the various parameters, such as $\mathrm{C}$ input quantities and weather data.

Note that the $\mathrm{C}$ inputs to RothC are not plant-specific, but rather are generic quantities that are adjustable in order to fit the model to the observed data. Calculating changes in $\mathrm{C}$ inputs over time is complicated by biomass increases due to management factors such as changing cultivars to improved varieties, which occurred occasionally over the experimental period, and decreasing row spacing for corn and soybeans, which occurred in 1972 (Dick et al. 1986a, 1986b). It is reasonable to expect that these variables may change in the future as well, but this study assumes they remain as-is from 2015 forward.

RothC calculates TOC in two phases: equilibrium and short term. For the model to arrive at the TOC content at equilibrium most accurately, the following information should be known, or estimated as accurately as possible:

- date of land use change when the site was originally converted from a natural ecosystem (and was assumed to be at a state of SOC equilibrium);
- type of the natural ecosystem (such as forest or grassland); and

- measured TOC content of the natural ecosystem before land use change.

The short-term calculation phase adjusts the TOC based on subsequent management and climate changes.

Because the information noted above for the equilibrium phase was unknown for either site, an estimate was made based on the given data and local knowledge about the sites. At Wooster, it was noted that the land was maintained as a grassland for six years prior to the beginning of the experimental period (Dick et al. 1986a). Therefore, it was assumed that the site was forest until 1956, grassland until 1961, then converted to cultivation in 1962. At Hoytville, Dick et al. (1986b) note the site was cropped for six years prior to the experimental period. However, they also noted that drainage tiles were installed in 1952, implying the site had been under cultivation for some time prior to that. Also, given the very high initial SOC percentage in 1963, and communication from Glover Triplett (one of the founding scientists for the agricultural experiment) indicating that the original ecosystem for this site was forest (personal communication, October 17,2016), it was assumed this survey sample was taken from a forest site and represents the initial SOC level at equilibrium at this site. This 1963 sample was collected within $1 \mathrm{~km}(0.6 \mathrm{mi})$ of the research plots. The soil at the Hoytville site is within a level and broad lake plain area in northwest Ohio. Therefore, little change over distances such as $1 \mathrm{~km}$ would be expected. Because the TOC levels during the experimental period were considerably lower than this initial measurement, it was assumed that the land had been under cultivation for some time. Therefore, several scenarios with different original land conversion dates were run to find the best fit with the data: 1868, 1915, and 1940. Of the three, 1915 provided the most plausible reproduction of the experimental period and was used as the date to equilibrium and initial land use change. It was also assumed that conventional PT cropping was practiced from land conversion until the experimental period began in 1963 .

For the best-fit runs at Wooster, average weather (NOAA data set, averaged from 1948 to 1961) was used through equilibrium in 1956. From 1956 through 1961, actual NOAA weather and grassland management were used. 


\section{Figure 1}

Wooster bulk density and soil organic carbon (C) contents over time in (a) no-tillage plots (to $25 \mathrm{~cm}$ ) and (b) plow-tillage plots (to $25 \mathrm{~cm}$ ). Dashed lines follow the full set of recorded data from experiment initiation, including initial measurements taken off-site. Solid lines only follow data actually collected from the site, excluding post-2006 samples at the plow-tillage site after field leveling. Round and square data points indicate bulk density and organic $C$, respectively. Starred $\left({ }^{*}\right)$ points represent bulk density values calculated from the bulk density trend line.

(a)

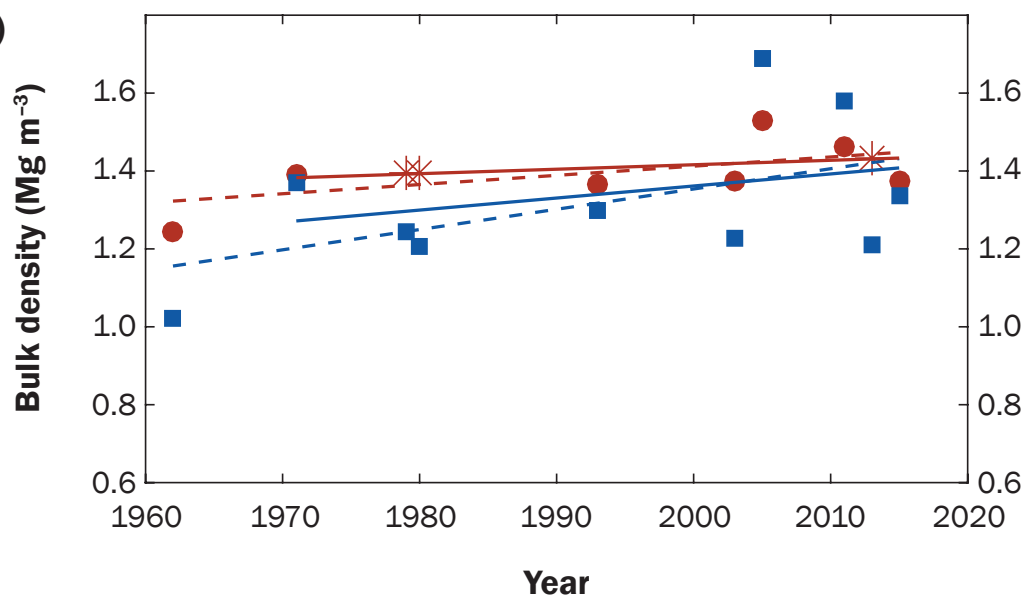

(b)

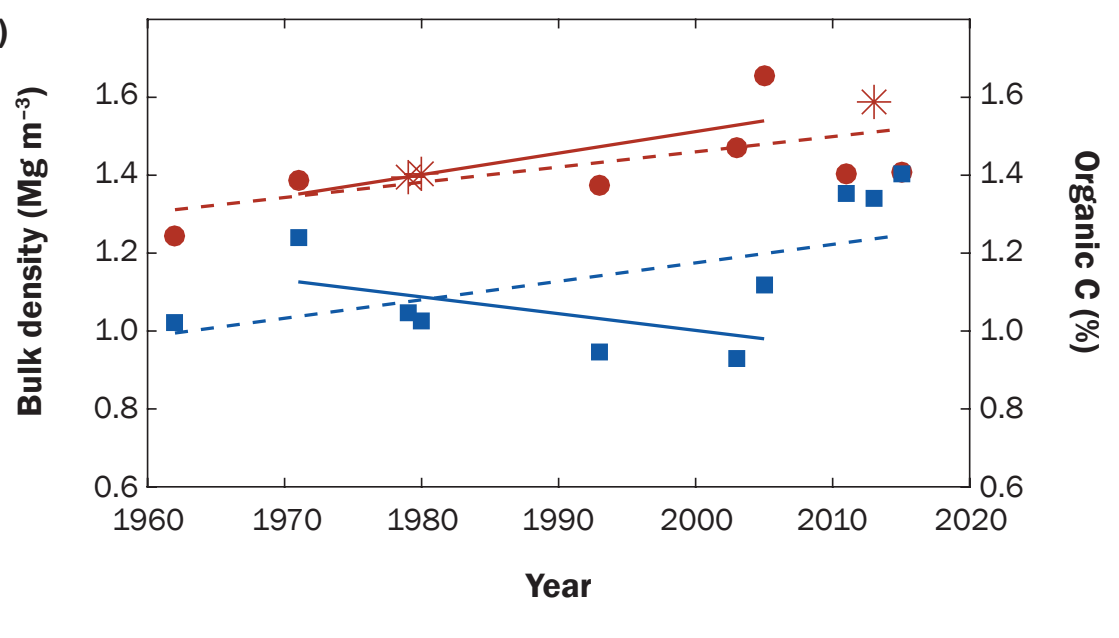

From 1962 through 2015, actual NOAA weather and average land management for cultivation (NT or PT) were used. At Hoytville, average weather (NOAA data set, averaged from 1953 to 1962) was used through equilibrium at 1915. From 1915 to 1953, average weather (1953 to 1962) and average land management for PT cultivation were used. From 1953 through 1962, actual weather and average PT cultivation were used. From 1963 through 2015, actual weather and average land management (NT or PT) were used.

For the LE projection runs, the same data were used as the best-fit runs (above) through 2015, then NOAA weather data averaged from 1985 through 2015 were used for the projection from 2016 through 2070.
For the HE projection runs, the same data were used as the best-fit runs through 1968. From 1969 through 2000, the CRCM historical reproduction weather data were used. From 2000 through 2037, the average weather from the combined CRCM historical and future data sets were used to fill in the gap until the CRCM future predictive weather data could be used from 2038 through 2070 .

\section{Results and Discussion}

As noted earlier, there have been a growing number of authors in recent years who have pointed out limitations to assigning NT as a universal panacea to mitigate climate change through the removal of atmospheric $\mathrm{CO}_{2}$ into long-term storage in the soil (Gregorich et al. 2007; Blanco-Canqui and Lal 2008; Hammons 2009; Powlson et al. 2014; VandenBygaart 2016). Four reasons include (1) the stratification of SOC in the profile of NT soils and its concentration at the surface to $20 \mathrm{~cm}$ (8 in) relative to PT soils (Powlson et al. 2014), with the implication that SOC is merely redistributed, rather than accumulated, over time; (2) climatic limitations, such as the cool, moist region of eastern Canada (Gregorich et al. 2007); (3) the definition of "no-till" itself, which can include occasional tillage (VandenBygaart 2016); and (4) a high spatial variability at the farm scale (Blanco-Canqui and Lal 2008). These concerns are specifically addressed in this study as follows: (1) there is evidence of SOC stratification under NT at both sites in this study, but total SOC content in the full topsoil layer did increase over time in some situations; (2) the research sites are in a temperate-zone climate, which indicates good potential for SOC sequestration (Lal 2004b); (3) the NT sites in this study were never tilled from initiation; and (4) while spatial variability remains a concern, the temporal scale provides a means to prove the differences between treatments over time.

Observed Values. Tables 1 and 2 and figures 1 through 3 document and illustrate considerable variability in measurements over the years, particularly in post-2000 samples. In such long-term studies that span many years and include various people involved in collecting and analyzing samples, variation such as reported here is not surprising. There are many avenues of variability possible. Differences in procedures as seemingly minor as how the surface residue was scraped off can affect the OC measurement. Also, samples were taken to different depths in different years. Stratification of OC and extrapolation calculations can add variability to the results.

At both sites, soil under NT showed higher TOC than that under PT (figure 3). This corresponds with earlier results published for these same two sites, which found significantly higher levels of TOC under NT as compared to PT, as well as stratification (Dick et al. 1986a, 1986b, 1991). Considering the large body of evidence in the literature that NT methods usually result in higher TOC than PT in the top $20 \mathrm{~cm}$ (8 in) of soil, and that PT methods usually result in TOC declines, the corroborative evidence in this study is no surprise. However, that TOC at all sites and treatments in this study are trending downward (figure 3) with the 


\section{Figure 2}

Hoytville bulk density and soil organic carbon (C) contents over time in (a) no-tillage plots (to $23 \mathrm{~cm}$ ) and (b) plow-tillage plots (to $23 \mathrm{~cm}$ ). Dashed lines follow the full set of recorded data from experiment initiation, including initial measurements taken off-site. Solid lines only follow data actually collected from the site. Round and square data points indicate bulk density and organic C, respectively. Starred $\left({ }^{*}\right)$ points represent bulk density values calculated from the bulk density trend line.

(a)

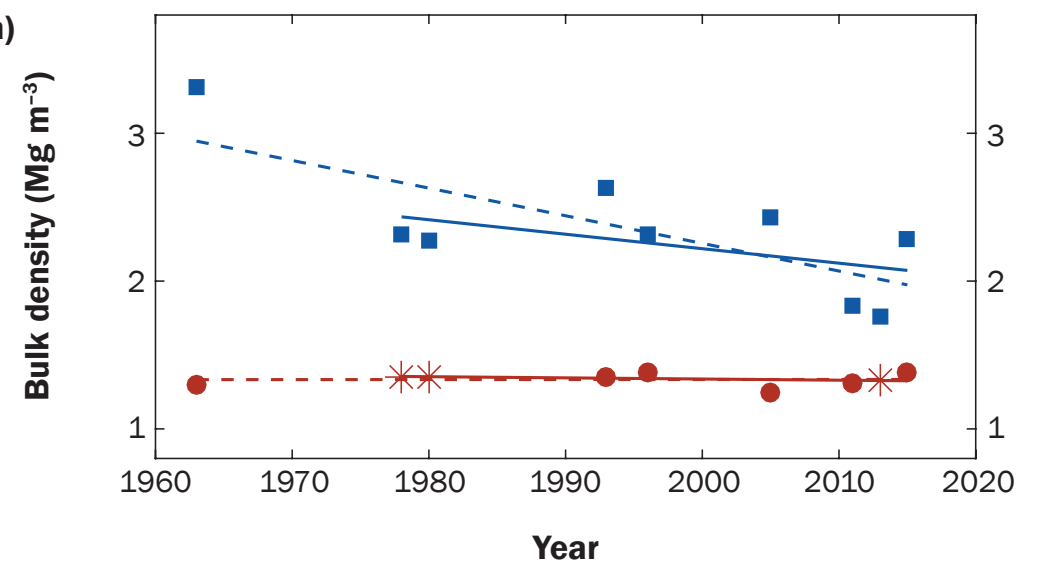

(b)

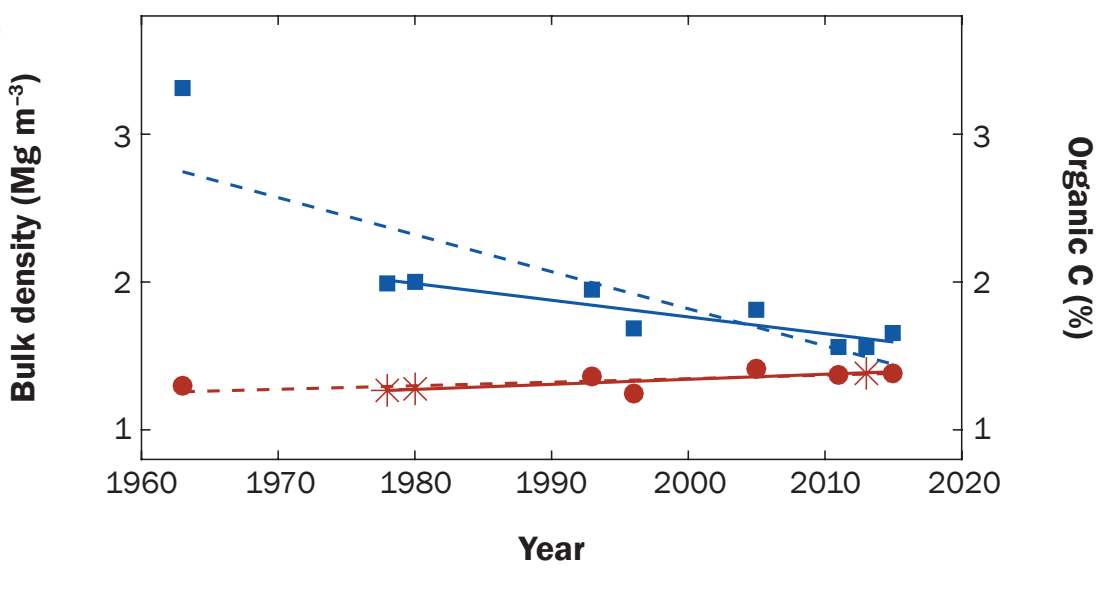

exception of NT at Wooster is a surprise. Given the relatively level slope of Hoytville $(<1 \%$ grade), its losses cannot be attributed to erosion, which could have been a factor at Wooster (2.5\% to $4 \%$ slope gradient), yet does not appear to be a significant factor in the NT treatment there.

Hoytville is virtually level with a high clay content and Wooster has a slope with low clay content. It was expected that Hoytville NT would be increasing in TOC, while PT decreased. Due to the slope and low clay content at Wooster, it was expected that TOC in NT would decrease or hold steady and PT would decrease. These expectations held true for Wooster, but not for Hoytville. Clay affects both the water holding capacity (Williams et al. 1983; Saxton and Rawls 2006) and the proportion of $\mathrm{CO}_{2}$ evolved to biomass and humus formed (Jenkinson et al. 1987; Coleman and Jenkinson 2014). In general, soils with higher clay build up slightly more SOC than those with lower clay, and this could explain the overall difference in TOC content between the sites. However, soils with higher clay hold more water than those with lower clay, which combined with the effects of cultivation management could result in increased decomposition rates of $\mathrm{OM}$ and decreasing rates of TOC at Hoytville.

An additional factor may lie in the climate trends over each site. Figure 4 illustrates observed (NOAA) climate changes of a $1.1^{\circ} \mathrm{C}\left(2^{\circ} \mathrm{F}\right)$ increase in average annual temperature and $27 \mathrm{~cm}$ (10.6 in) increase in total annual precipitation at Wooster and a $0.75^{\circ} \mathrm{C}\left(1.35^{\circ} \mathrm{F}\right)$ increase in average annual temperature and $11.2 \mathrm{~cm}$ (4.4 in) increase in total annual precipitation at Hoytville over the duration of their respective experimental periods. Given that increases in temperature and precipitation can increase rates of SOC decomposition (Kirschbaum 1995; Cook and Orchard 2008), this could account for some of the overall reductions, or for such modest increases, in TOC at each site, although the effect of temperature on the rate of OM decomposition is a subject of ongoing debate (Conant et al. 2011).

Best-Fit and Projection Runs. The left sides of figures 5 and 6 provide the results of the historical reconstruction (best-fit) runs through 2015 against the considerable scatter of data points at both sites. The two model runs for this study have a variable degree of correlation with the observed data. While the Hoytville runs show a statistically significant correlation, the Wooster runs do not (figure 7). However, the RothC model results reflect the expectation that SOC changes slowly over time. The observed measurements may not be a realistic progression of how $\mathrm{C}$ changes in soil, such as about a $14 \mathrm{Mg}$ $\mathrm{C} \mathrm{ha}^{-1}$ (6.24 tn $\mathrm{C} \mathrm{ac}^{-1}$ ) gain and subsequent loss within the span of a few years (for example, see table 1, years 2003 to 2005 and 2011 to 2013). RothC will not reflect the high variability apparent in the data collection, resulting in a diminished statistical correlation, but it does capture the overall trend.

The ideal starting point for RothC to calculate SOC changes in soil is from the point of land use change, such as from native grassland or forest to cultivated field. The model starts its process by calculating the build-up of $\mathrm{C}$ levels for the prior 10,000 years leading up to levels measured at the experiment initiation, at which point it assumes the $\mathrm{C}$ levels are at equilibrium, and entered into the model as monthly input of plant residues in megagrams of $\mathrm{C}$ per hectare (Coleman and Jenkinson 2014). Once the modeling run begins, $\mathrm{C}$ input levels are entered for each year based either on cropping and yield data, or simply adjusted to best match the TOC measured during the experiment (the latter method was used in this study).

As explained earlier, the actual dates of conversion of the Wooster and Hoytville sites from natural ecosystem to agriculture were estimated. Since the dates of the initial soil samples were set internally in RothC to 1956 and 1915 for Wooster and Hoytville, respectively, the TOC levels that RothC arrived at by each experimental period (table 3) serve as proxy starting TOC levels for the analysis for this study.

Also explained earlier, the model uses NOAA averaged or observed climate data 


\section{Figure 3}

Observed total organic carbon (C) content (corrected to equivalent soil mass) for data actually collected from (a) the Wooster site (3,115 Mg ha ${ }^{-1}$ at approximately $25 \mathrm{~cm}$ depth) and (b) the Hoytville site $(2,990$ $\mathrm{Mg} \mathrm{ha}^{-1}$ at approximately $23 \mathrm{~cm}$ depth), with trend lines (solid and dashed representing no-till and plowtill, respectively). Wooster plow-till data excludes post-2006 samples at the site after field leveling.

(a)

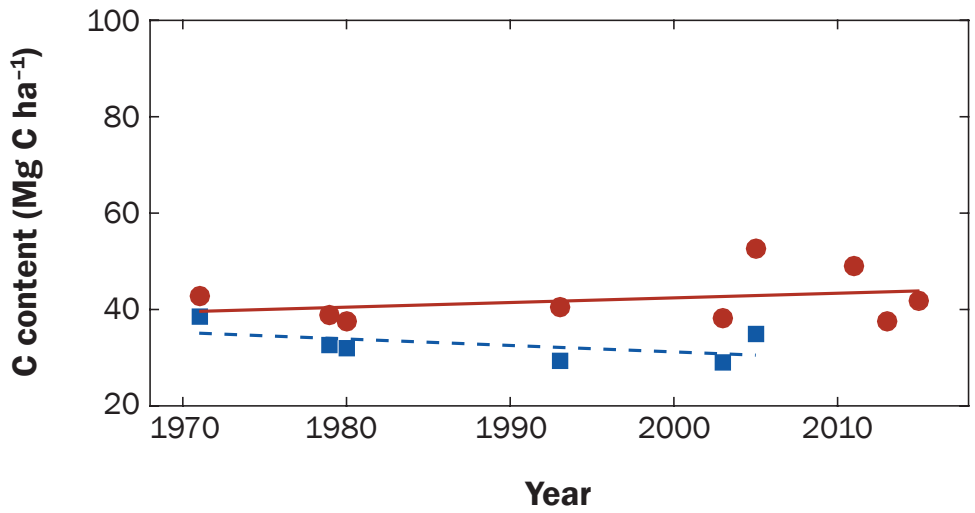

(b)

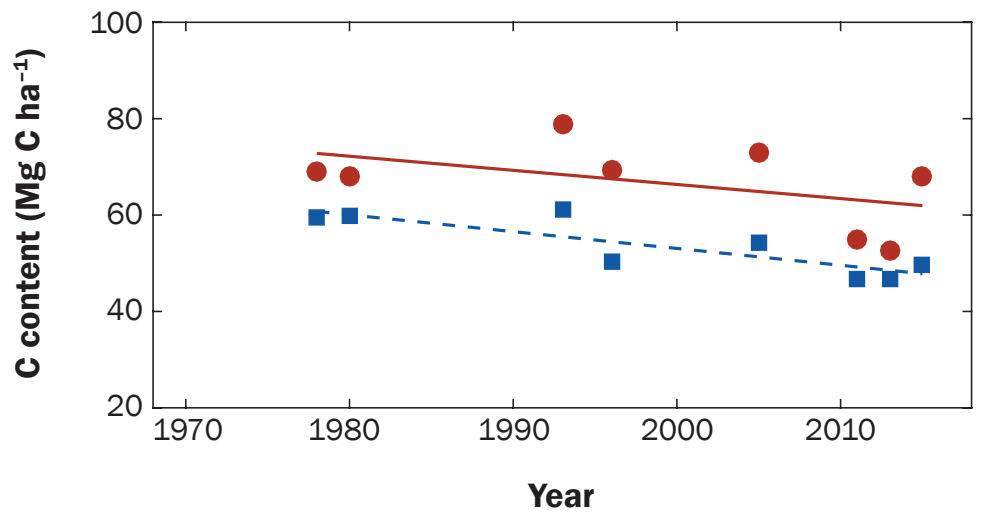

Legend

No-till

- Plow-till

through 1967, then output from the CRCM historical reconstruction 1968 through 2000. A distinct divergence occurs from 1968 in both sites and treatments with the CRCM model indicating drops in TOC levels from 1968 almost continuously through 2070, resulting in about 29\% less TOC at Wooster between the LE and HE scenarios for both treatments, and about 22\% less TOC at Hoytville between the scenarios for both treatments. The initial drop in TOC levels may be explained by the differences in precipitation between the CRCM and NOAA data. Figure 4 compares the temperature and precipitation over each site by the CRCM model versus NOAA observed values. The CRCM simulates lower temperatures as compared to NOAA values, which would indicate a lower rate of decomposition, though both trend upwards. Precipitation simulated by the CRCM is substantially different, however, starting in 1968 with $130.4 \mathrm{~cm}$ (51.3 in) total precipitation compared to $87.2 \mathrm{~cm}$ (34.3 in) total reported by NOAA and trending slightly downward. With a linear relationship between soil respiration (and therefore OM decomposition) and soil water content (Cook and Orchard 2008), moisture plays a significant role in the decomposition of SOC.

The right sides of figures 5 and 6 show the results of the projection runs. Table 3 shows that three tests resulted in TOC increases over the projection period (2015 through 2070): (1) Wooster NT under LE, (2) Wooster PT under LE, and (3) Hoytville NT under LE. Because Wooster NT was trending gently upwards prior to the future projection, this increase was expected. However, the increase for Wooster PT was not expected. All remaining treatment and scenario combinations resulted in TOC decreases, as expected. However, these results are based on the total increases or decreases over the total projection period. These increases only hold through 2050. From 2050 through 2070, both treatments at both sites-with the exception of NT at Wooster under LEshow a decreasing trend in TOC (table 3).

The LE scenario assumes climate change halts at the 1985 to 2015 average, so the modest gains (or minimal loss) indicated in figures 5 and 6 are unlikely. The results of the HE scenario are most likely influenced by the heavy precipitation increases predicted by the CRCM model in both summer and winter, as well as increases in temperature (figure 4). After the CRCM projected weather data begins in 2038, the Wooster site begins to show a small climate signal from 2050 to 2070 with hints of the drop in TOC projected by Jones et al. (2005) using RothC and the HadCM3 GCM.

The scenarios as constructed in this study have some attributes that are unrealistic, but both are legitimate for the purpose they serve, which is to delineate the most likely upper and lower bounds on the trend of SOC accumulation/loss over time. For example, LE represents a best-case scenario ("What if climate change stopped at the current 31-year average?”). Though unrealistic, it serves as a projected baseline to compare to HE, which represents the worst-case scenario ("What if emissions continue to increase?"), which is actually not at all unrealistic (IPCC 2013). But the regional climate model chosen (in fact, all in the NARCCAP project) also has a higher temperature and precipitation bias over observed values for this specific region, which exaggerates the already worstcase scenario, but therefore serves its purpose as a lower bound.

Mearns et al. (2013) explain the status of RCM consistency and reliability as follows. All RCMs show biases. In general, GCM and RCM precipitation projections for the winter season over the eastern portion of the Midwest, including Ohio, are in agreement. However, there is no agreement between GCM and RCM projections of summer precipitation over the Midwest as a whole. The Great Lakes region presents a particular challenge for RCMs, due to issues representing the lakes, or to errors related to the setup of the lake models (Mearns et al. 2013).

Although higher precipitation amounts are projected into the future by the CRCM model for Ohio, GCMs are projecting that much of this precipitation increase will occur in heavier events (Melillo et al. 2014; Collins et al.2013). A result could be drier soils over- 


\section{Figure 4}

Trends in temperature and precipitation over (a) Wooster and (b) Hoytville for weather data used to build the low-emissions (observed data) and high-emissions (modeled data) scenarios. Red lines (lower three in each graph) are annual mean temperature. Blue lines (upper three in each graph) are annual total precipitation. Solid lines are from observed (NOAA) values over the duration of the respective experimental periods. Dashed lines are modeled (CRCM historical reproduction) values from 1968 to 2000. Dash-dot lines are modeled (CRCM future projection) values from 2038 to 2070 .

(a)

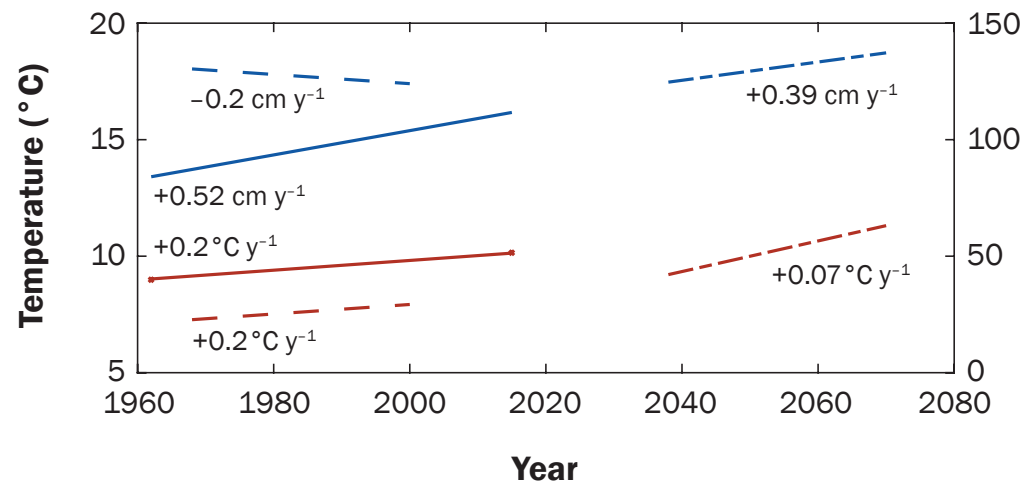

(b)

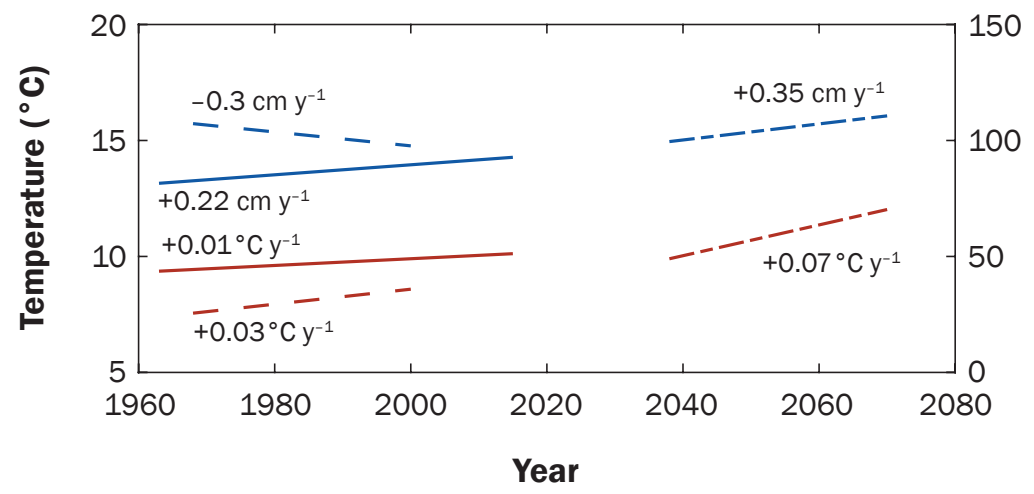

et al. 2012; Pereira et al. 2013; van Groenigen et al. 2014). Explanations include increased labile substrate availability (the priming effect) and changes in microbial composition leading to increased microbial utilization of soil C (Carney et al. 2007). Despite increases in C inputs due to stimulated plant growth at $\mathrm{eCO}_{2}$, both plant-based and microbial responses may more than counter it, resulting in overall losses of SOC (van Groenigen et al. 2014). It has been also reported that additions of $\mathrm{N}$ over natural rates of atmospheric inputs are required in order to affect $\mathrm{C}$ sequestration under $\mathrm{eCO}_{2}$ (van Groenigen et al. 2006), and this is common in corn-based agricultural systems in the United States. Finally, recent studies (Hopkins et al. 2014; Osanai et al. 2015) have found the combined effects of $\mathrm{eCO}_{2}$ and increased temperature on the rate of decomposition to be greater than under either effect alone. In summary, $\mathrm{eCO}_{2}$ effects were not factored into the results, but increased growth could impact how $\mathrm{C}$ is processed and stored in soil. One possible result of $\mathrm{eCO}_{2}$ is the accumulation of SOC, and another is soil becoming a $\mathrm{C}$ source in the future, rather than a sink (Carney et al. 2007).

\section{Summary and Conclusions}

With climate change threatening to be a substantial challenge to future soil health, this study sought to determine how SOC levels will respond to climate change. We observe and conclude the following:

- From 2015 through 2070, SOC content in the full topsoil layers is projected to decrease under all sites and management in this study with the exception of NT at Wooster and Hoytville and PT at Wooster under the LE scenario, and final SOC content is projected to be lower under a HE than a LE scenario.

- Additionally, all sites and treatments, with the exception of NT at Wooster under LE, show decreasing trends of SOC over the second half of the projection period (2050 to 2070), which is in general agreement with projections by Jones et al. (2005).

- We feel with reasonable confidence that the upper limit of SOC content predicted by the LE scenario will not be exceeded given the parameters of this study, and most likely not even attained due to the high certainty by climate scientists that the effects of climate change will continue over the time period in this study, though the effects of $\mathrm{eCO}_{2}$ remain uncertain. 


\section{Figure 5}

Results of modeling runs for Wooster (a) no-till and (b) plow-till sites under low- and highemissions scenarios (upper and lower lines in each graph, respectively) comparing modeled total organic carbon (TOC) to observed TOC, corrected to equivalent soil mass (ESM), which equates to approximately $25 \mathrm{~cm}$ depth at this site. The dashed vertical line divides the graph into historical reconstruction (best-fit) and projection periods.

(a)

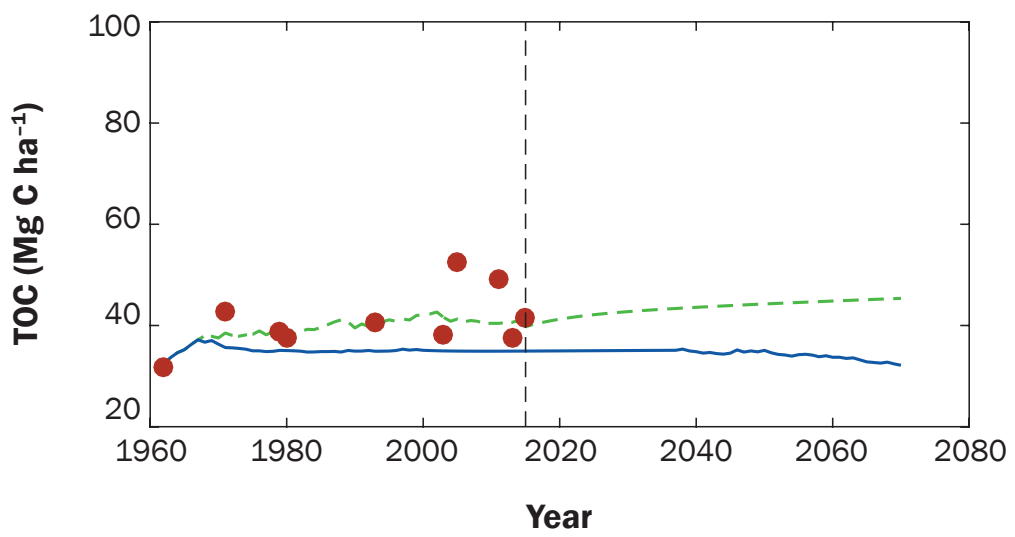

(b)

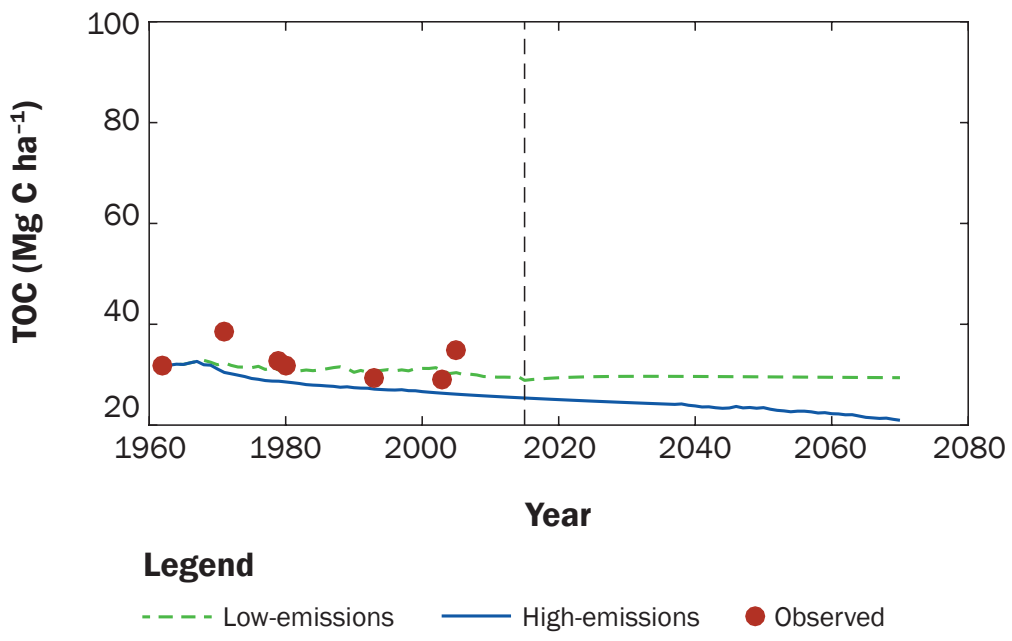

- The accuracy of the lower limit predicted by the HE scenario is suspect due to the evident inability of the CRCM to replicate historical climate conditions local to the two sites, and so we believe this prediction to be too low. Therefore, we expect with reasonable confidence that the actual future levels of SOC will fall within the range bounded by the LE and HE predicted levels.

- Although there is some uncertainty integrated into the results of this study, observed values are already indicating downward trends in SOC in recent years, many of which are among the warmest on record globally (Cole and McCarthy 2015) and under increases in local precipitation trends.

- Extrapolation from this study suggests that some current farming practices, on soils and in climates similar to those at into the Northeast. $\mathrm{C}$ inputs and its decomposition.

\section{Acknowledgements}

This research is part of a regional collaborative project supported by the USDA National Institute of Food and Agriculture (NIFA), Award No. 2011-68002-30190, Cropping Systems Coordinated Agricultural Project: Climate Change, Mitigation, and Adaptation in Cornbased Cropping Systems. Additional funding was provided through the Katherine M. Grosscup Scholarship from The Garden Club of America. Gratitude is also extended to the Carbon Management and Sequestration Center at The Ohio State University in Columbus, Ohio, and to the following individuals who provided expertise and general assistance: Jose Guzman (research associate, Carbon Management and Sequestration Center, The Ohio State University, Columbus, Ohio), Chris Eidson (agronomist, Brookside Laboratories, New Bremen, Ohio), Pat Bell (product innovations manager, One Acre Fund, Kakamega, Kenya), Nall Moonilall (graduate teaching assistant, Carbon Management and Sequestration Center, The Ohio State University, Columbus, Ohio), Reed Johnson (graduate research associate, Carbon Management and Sequestration Center, The Ohio State University, Columbus, Ohio), Laura Conover (office associate, Carbon Management and Sequestration Center, The Ohio State University, Columbus, Ohio), and Dirk Maas (St. Louis, Missouri).

\section{References}

Abebe, A., H. Pathak, S.D. Singh, A. Bhatia, R.C. Harit, and V. Kumar. 2016. Growth, yield and quality of maize with elevated atmospheric carbon dioxide and temperature in north-west India. Agriculture, Ecosystems and Environment 218:66-72.

Angers, D.A., and N.S. Eriksen-Hamel. 2008. Full-inversion tillage and organic carbon distribution in soil profiles: A meta-analysis. Soil Science Society of America Journal 72(5):1370-74

Attavanich,W., and B.A. McCarl. 2014. How is $\mathrm{CO}_{2}$ affecting yields and technological progress? A statistical analysis. Climatic Change 124(4):747-62.

the Wooster and Hoytville sites, may not be able to be sustained in the long term under climate change. Combined, these sites are representative of around 24,000 $\mathrm{km}^{2}$ (around 9,000 $\mathrm{mi}^{2}$ ) of cropped agricultural land in the United States across the northern regions of the Midwest and

- For more effective future modeling including climate change, regional models should (1) provide projections that match IPCC LE and HE scenarios through 2100 , (2) improve precipitation projections, and (3) provide continuous data from historical reconstructions through future projections. Additionally, SOC models should incorporate the effects of $\mathrm{eCO}_{2}$ with increases both of plant-based
Basche, A.D., S.V. Archontoulis, T.C. Kaspar, D.B. Jaynes, T.B. Parkin, and F.E. Miguez. 2016. Simulating longterm impacts of cover crops and climate change on crop production and environmental outcomes in the midwestern United States. Agriculture, Ecosystems and Environment 218:95-106.

Blanco-Canqui, H., and R. Lal. 2008. No-tillage and soilprofile carbon sequestration: An on-farm assessment. Soil Science Society of America Journal 72(3):693-701.

Bukovsky, M.S. 2011. Masks for the Bukovsky regionalization of North America. Boulder, CO: Regional Integrated Sciences Collective, Institute for Mathematics Applied to Geosciences, National Center for Atmospheric Research. http://www.narccap.ucar.edu/contrib/bukovsky/.

Carney, K.M., B.A. Hungate, B.G. Drake, and J.P. Megonigal. 2007. Altered soil microbial community at elevated $\mathrm{CO}_{2}$ leads to loss of soil carbon. Proceedings of the National 


\section{Figure 6}

Results of modeling runs for Hoytville (a) no-till and (b) plow-till under low- and high-emissions scenarios (upper and lower lines in each graph, respectively) comparing modeled total organic carbon (TOC) to observed TOC, corrected to equivalent soil mass (ESM), which equates to approximately $23 \mathrm{~cm}$ depth at this site. The dashed vertical line divides the graph into historical reconstruction (best-fit) and projection periods.

(a)

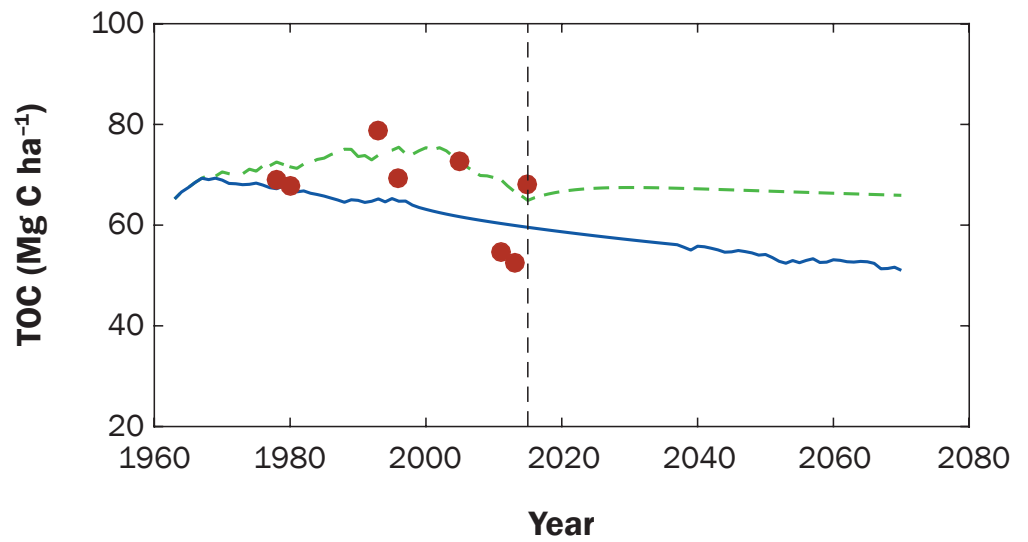

(b)

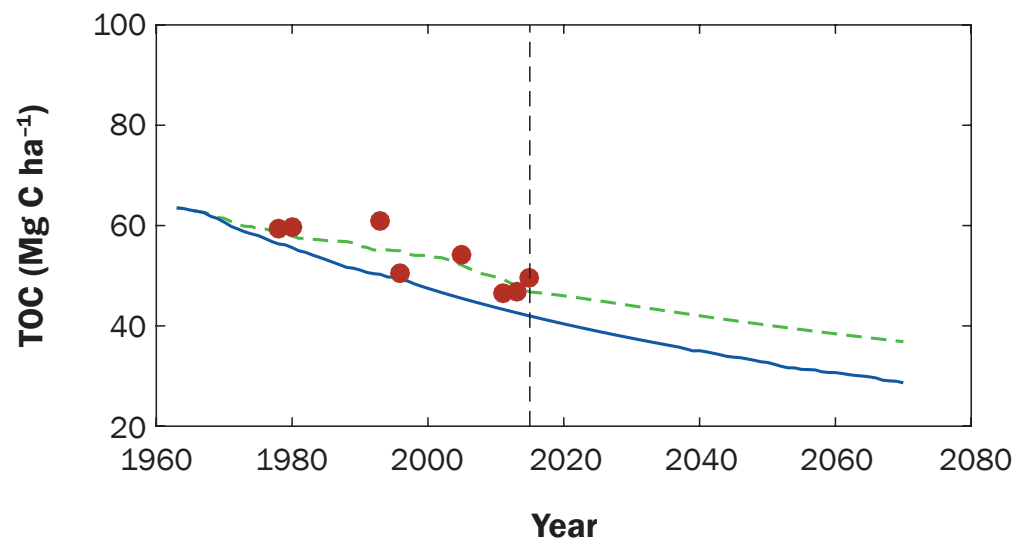

Legend

- - - - Low-emissions

High-emissions

Observed

Academy of Sciences of the United States of America 104(12):4990-95.

Cheng, L., F.L. Booker, C. Tu, K.O. Burkey, L. Zhou, H.D. Shew,T.W.Rufty, and S.Hu. 2012.Arbuscular mycorrhizal fungi increase organic carbon decomposition under elevated $\mathrm{CO}_{2}$. Science 337:1084-87.

Cole, S., and L. McCarthy. 2015. 2014 Warmest Year in Modern Record. Climate Change: Vital Signs of the Planet, January 16, 2015. http://climate.nasa.gov/ news/2221/2014-warmest-year-in-modern-record/.

Coleman, K., and D.S. Jenkinson. 2014. RothC: A Model for the Turnover of Carbon in Soil. Harpenden, UK: Rothamsted Research.

Collins, M., R. Knutti, J. Arblaster, J.L. Dufresne, T. Fichefet, P. Friedlingstein, X. Gao, W.J. Gutowski,T. Johns, G. Krinner, M. Shongwe, C.Tebaldi,A.J.Weaver, and M.Wehner. 2013. Long-term Climate Change: Projections, Commitments and Irreversibility. In Climate Change 2013: The Physical Science Basis. Contribution of Working Group I to the Fifth Assessment Report of the Intergovernmental Panel on Climate Change, eds. T.F. Stocker, D. Qin, G.-K. Plattner, M. Tignor, S.K. Allen, J. Boschung, A. Nauels, Y. Xia,V. Bex, and P.M. Midgley. Cambridge, UK, and New York, NY, USA: Cambridge University Press.

Combs, S.M., and M.V. Nathan. 1998. Chapter 12: Soil Organic Matter. In Recommended Chemical Soil Test Procedures for the North Central Region. North Central Regional Research Publication No. 221. Missouri Agricultural Experiment Station Bulletin 1001. Conant, R.T., M.G. Ryan, G.I. Ågren, H.E. Birge, E.A. Davidson, P.E. Eliasson, S.E. Evans, S.D. Frey, C.P. Giardina, F.M. Hopkins, R. Hyvonen, M.U.F. Kirschbaum, J.M. Lavallee, J. Liefeld, W.J. Parton, J.M. Steinweg, M.D. Wallenstain, J.A.M. Wetterstedt, and M.A. Bradford. 2011. Temperature and soil organic matter decomposition rates: Synthesis of current knowledge and a way forward. Global Change Biology 17(11):3392-3404.

Cook, FJ., and V.A. Orchard. 2008. Relationships between soil respiration and soil moisture. Soil Biology and Biochemistry 40(5):1013-18.
CSCAP (Cropping Systems Coordinated Agricultural Project). 2016.About this Project. Sustainable Corn.Org - Crops, Climate, Culture and Change. http://www. sustainablecorn.org/About-Project/Index.html.

Cubasch, U., D. Wuebbles, D. Chen, M.C. Facchini, D. Frame, N. Mahowald, and J.-G. Winther. 2013. Introduction. In Climate Change 2013: The Physical Science Basis. Contribution of Working Group I to the Fifth Assessment Report of the Intergovernmental Panel on Climate Change, eds. T.F. Stocker, D. Qin, G.-K. Plattner, M. Tignor, S.K. Allen, J. Boschung, A. Nauels, Y. Xia, V. Bex, and P.M. Midgley. Cambridge, UK, and New York, NY, USA: Cambridge University Press.

Dick, W.A. 1983. Organic carbon, nitrogen, and phosphorus concentrations and $\mathrm{pH}$ in soil profiles as affected by tillage intensity. Soil Science Society of America Journal 47:102-107.

Dick, W.A., E.L. McCoy, W.M. Edwards, and R. Lal. 1991. Continuous application of no-tillage to Ohio soils. Agronomy Journal 83:65-73.

Dick, W.A., G.B.Triplett, and D.M.Van Doren. 2013.TriplettVan Doren Long-Term Tillage and Crop Rotation Data. Wooster, OH: Ohio Agricultural Research and Development Center, The Ohio State University. http://hdl.handle.net/1811/55716.

Dick, W.A., D.M. Van Doren Jr., G.B. Triplett Jr., and J.E. Henry. 1986a. Influence of long term tillage and rotation combinations on crop yields and selected soil parameters. II. Results obtained for a Typic Fragiudalf soil. Research Bulletin 1181. Wooster, OH: Ohio Agricultural Research and Development Center, The Ohio State University.

Dick, W.A., D.M. Van Doren Jr., G.B. Triplett Jr., and J.E. Henry. 1986b. Influence of long term tillage and rotation combinations on crop yields and selected soil parameters. I. Results obtained for a Mollic Ochraqualf soil. Research Bulletin 1180. Wooster, OH: Ohio Agricultural Research and Development Center, The Ohio State University.

Dijkstra, F.A., and J.A. Morgan. 2012. Elevated $\mathrm{CO}_{2}$ and Warming Effects on Soil Carbon Sequestration and Greenhouse Gas Exchange in Agroecosystems. In Managing Agricultural Greenhouse Gases, 467-86. London: Elsevier. http://linkinghub.elsevier.com/ retrieve/pii/B9780123868978000279.

Dold, C., H. Büyükcangaz, W. Rondinelli, J.H. Prueger, T.J. Sauer, and J.L. Hatfield. 2017. Long-term carbon uptake of agro-ecosystems in the Midwest. Agricultural and Forest Meteorology 232:128-40.

ECCC (Environment and Climate Change Canada). 2016. The Third Generation Coupled Global Climate Model. ECCC. http://www.ec.gc.ca/ccmac-cccma/default. asp?lang=En\&n=1299529F-1.

Evrendilek, F., and M.K. Wali. 2001. Modelling long-term C dynamics in croplands in the context of climate change: A case study from Ohio. Environmental Modelling and Software 16(4):361-75. 


\section{Figure 7}

Correlation diagrams between observed (equivalent soil mass; tables 1 and 2) and modeled total organic carbon (TOC) (table 3 ) for (a) Wooster notill, (b) Wooster plow-till, (c) Hoytville no-till, and (d) Hoytville plow-till sites, for the best-fit model runs corresponding to the low-emissions scenarios through 2015. Wooster plow-till diagram only includes data through 2005.

(a)

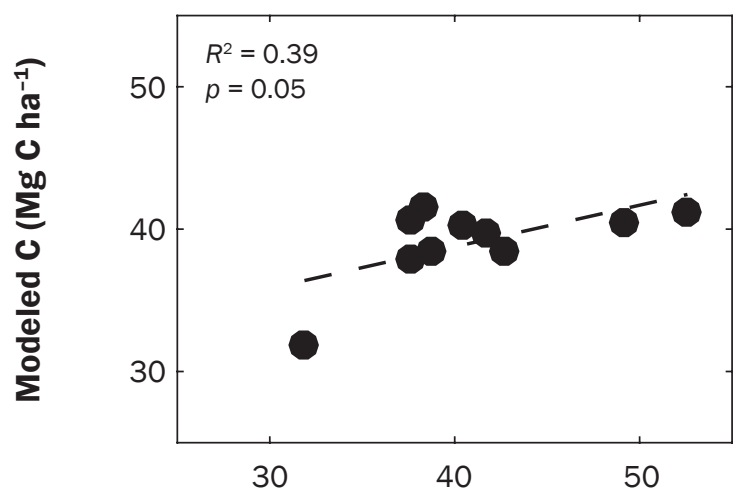

Observed C (Mg C ha-1)

(c)

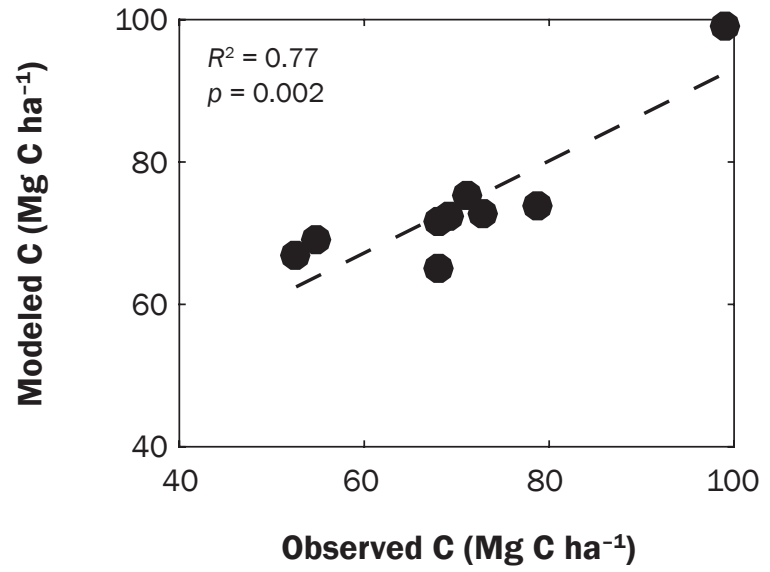

(b)

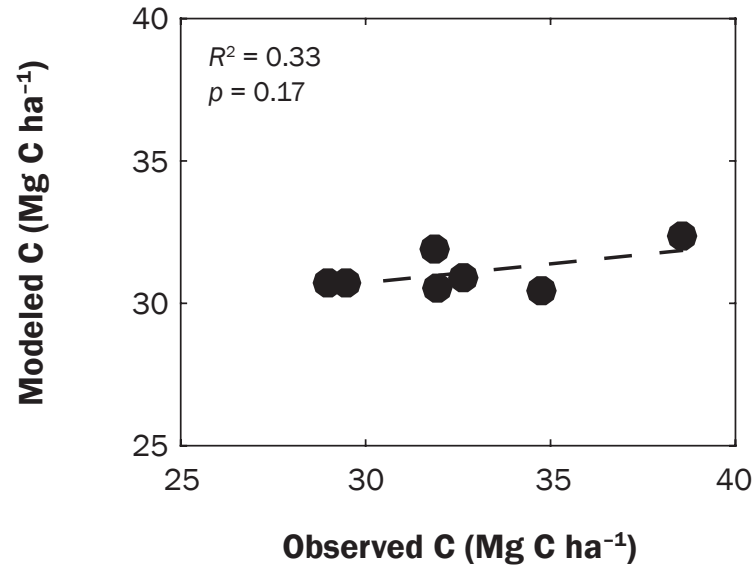

(d)

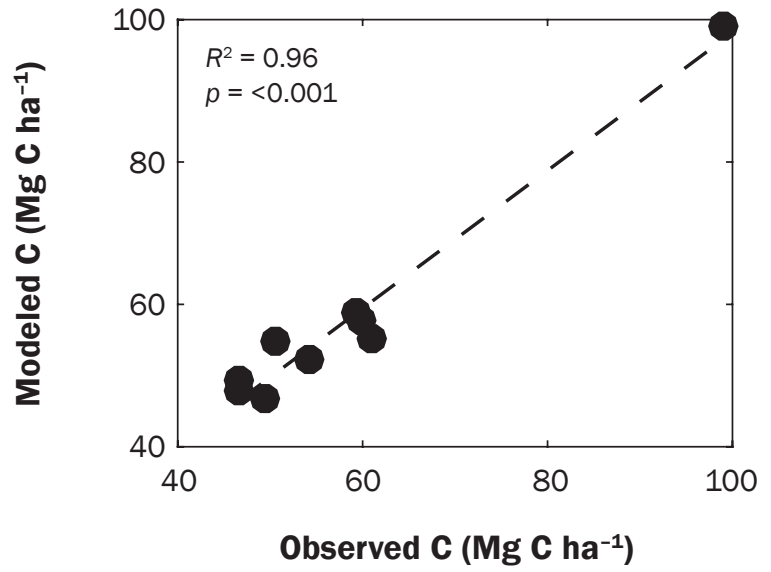

Evrendilek, F, and M.K.Wali. 2004. Changing global climate: Historical carbon and nitrogen budgets and projected responses of Ohio's cropland ecosystems. Ecosystems 7(4):381-392.

Gregorich, E.G., P. Rochette, A.J. VandenBygaart, and D.A. Angers. 2007. Greenhouse gas contributions of agricultural soils and potential mitigation practices in Eastern Canada. Soil and Tillage Research 83(1):53-72.

Hammons, S.K. 2009. Re-examining the relationship between tillage regime and global climate change. Journal of Natural Resources and Life Sciences Education 38:144-47.

Hatfield, J. 2012. Agriculture in the Midwest. In U.S. National Climate Assessment Midwest Technical Input Report. J. Winkler, J.Andresen, J. Hatfield, D. Bidwell, and D. Brown, coordinators. Available from the Great Lakes Integrated Sciences and Assessments (GLISA) Center. http://glisa. msu.edu/docs/NCA/MTIT_Agriculture.pdf.

Hatfield, J., G. Takle, R. Grotjahn, P. Holden, R.C. Izaurralde, T. Mader, E. Marshall, and D. Liverman. 2014. Chapter 6: Agriculture. In Climate Change Impacts in the United States: The Third National Climate Assessment, eds. J.M.
Melillo, T.C. Richmond, and G.W. Yohe, U.S. Global Change Research Program, 150-174.

Hobbs, P.R., K. Sayre, and R. Gupta. 2008. The role of conservation agriculture in sustainable agriculture. Philosophical Transactions of the Royal Society of London B: Biological Sciences 363(1491):543-55.

Hopkins, F.M., T.R. Filley, G. Gleixner, M. Lange, S.M. Top, and S.E. Trumbore. 2014. Increased belowground carbon inputs and warming promote loss of soil organic carbon through complementary microbial responses. Soil Biology and Biochemistry 76:57-69.

IPCC (Intergovernmental Panel on Climate Change). 2013. Summary for Policymakers. In Climate Change 2013:The Physical Science Basis. Contribution of Working Group I to the Fifth Assessment Report of the Intergovernmental Panel on Climate Change, eds. T.F. Stocker, D. Qin, G.-K. Plattner, M. Tignor, S.K. Allen, J. Boschung, A. Nauels, Y. Xia,V. Bex, and P.M. Midgley. Cambridge, UK, and New York, NY: Cambridge University Press.

IPCC. 2014. Climate Change 2014: Synthesis Report Contribution of Working Groups I, II and III to the Fifth
Assessment Report of the Intergovernmental Panel on Climate Change, eds. K. Pachauri and L.A. Meyer, 155. Geneva, CH: Intergovernmental Panel on Climate Change. Janetos, A., L. Hansen, D. Inouye, B.P. Kelly, L. Meyerson, B. Peterson, and R. Shaw. 2008. Biodiversity. In The effects of climate change on agriculture, land resources, water resources, and biodiversity in the United States. A Report by the U.S. Climate Change Science Program and the Subcommittee on Global Change Research. Washington, DC.

Jenkinson, D.S., P.B.S Hart, J.H. Rayner, and L.C. Parry. 1987. Modelling the turnover of organic matter in long-term experiments at Rothamsted. INTECOL Bulletin 15:1-8.

Jimenez, R., and J.K. Ladha. 1993. Automated elemental analysis: A rapid and reliable but expensive measurement of total carbon and nitrogen in plant and soil samples. Communications in Soil Science and Plant Analysis 24(15-16):1897-1924.

Jones, C., C. McConnell, K. Coleman, P. Cox, P. Falloon, D. Jenkinson, and D. Powlson. 2005. Global climate change and soil carbon stocks: Predictions from two contrasting 
Table 3

Selected total organic carbon (C) levels generated by the RothC model under low-emissions (LE) and high-emissions (HE) scenarios for no-till (NT) and plow-till (PT) treatments at both agricultural sites, including the calculated difference in modeled C levels over the projection period (2015 to 2070) and over the last two decades (2050 to 2070). For clarity to compare data to tables 1 and 2, data were omitted (with dashes) in the years during the experimental period (1962 to 2015) that do not correspond to years that physical samples were taken at each site.

\begin{tabular}{|c|c|c|c|c|c|c|c|c|}
\hline \multirow[b]{3}{*}{ Year } & \multicolumn{4}{|c|}{ LE scenario } & \multicolumn{4}{|c|}{ HE scenario } \\
\hline & \multicolumn{2}{|c|}{$\begin{array}{l}\text { Wooster modeled C } \\
\left(\mathrm{Mg} \mathrm{C} \mathrm{ha}^{-1}\right)\end{array}$} & \multicolumn{2}{|c|}{$\begin{array}{l}\text { Hoytville modeled C } \\
\left(\mathrm{Mg} \mathrm{C} \mathrm{ha}^{-1}\right)\end{array}$} & \multicolumn{2}{|c|}{$\begin{array}{l}\text { Wooster modeled C } \\
\left(\mathrm{Mg} \mathrm{C} \mathrm{ha-1)}^{-1}\right.\end{array}$} & \multicolumn{2}{|c|}{$\begin{array}{l}\text { Hoytville modeled C } \\
\left(\mathrm{Mg} \mathrm{C} \mathrm{ha-1)}^{-1}\right.\end{array}$} \\
\hline & NT & PT & NT & PT & NT & PT & NT & PT \\
\hline 1962 & 32.4 & 31.5 & - & - & 32.4 & 31.5 & - & - \\
\hline 1963 & - & - & 65.2 & 63.5 & - & - & 65.2 & 63.5 \\
\hline 1971 & 38.5 & 32.4 & - & - & 35.6 & 30.4 & - & - \\
\hline 1978 & - & - & 72.5 & 58.9 & - & - & 67.2 & 56.3 \\
\hline 1979 & 38.5 & 30.9 & - & - & 35.1 & 28.7 & - & - \\
\hline 1980 & 37.9 & 30.5 & 71.6 & 57.9 & 35.0 & 28.6 & 67.3 & 55.6 \\
\hline 1993 & 40.3 & 30.7 & 73.9 & 55.2 & 34.9 & 27.1 & 65.2 & 50.3 \\
\hline 1996 & - & - & 75.5 & 55.0 & - & - & 64.7 & 49.2 \\
\hline 2003 & 41.6 & 30.7 & - & - & 35.0 & 26.3 & - & - \\
\hline 2005 & 41.3 & 30.4 & 72.8 & 52.1 & 34.9 & 26.1 & 61.7 & 45.5 \\
\hline 2011 & 40.4 & 29.5 & 69.1 & 49.4 & 34.9 & 25.7 & 60.3 & 43.3 \\
\hline 2013 & 40.6 & 29.5 & 66.7 & 48.0 & 34.9 & 25.5 & 59.9 & 42.6 \\
\hline 2015 & 39.8 & 28.9 & 64.9 & 46.8 & 34.9 & 25.3 & 59.6 & 42.0 \\
\hline 2038 & 43.4 & 30.0 & 67.3 & 42.4 & 35.3 & 24.2 & 55.6 & 35.4 \\
\hline 2050 & 44.3 & 29.6 & 66.8 & 40.1 & 35.1 & 23.5 & 54.2 & 32.7 \\
\hline 2070 & 45.4 & 29.4 & 65.9 & 36.9 & 32.1 & 21.0 & 51.0 & 28.7 \\
\hline Difference & 5.6 & 0.5 & 1.0 & -9.9 & -2.8 & -4.3 & -8.6 & -13.3 \\
\hline 2015 to 2070 & $14.1 \%$ & $1.7 \%$ & $1.5 \%$ & $-21.2 \%$ & $-8.0 \%$ & $-17.0 \%$ & $-14.4 \%$ & $-31.7 \%$ \\
\hline Difference & 4.5 & 0.7 & 1.9 & -6.7 & 0.2 & -1.8 & -5.4 & -9.3 \\
\hline 2015 to 2050 & $10.3 \%$ & $2.2 \%$ & $2.8 \%$ & $-15.7 \%$ & $0.5 \%$ & $-7.6 \%$ & $-9.8 \%$ & $-26.2 \%$ \\
\hline Difference & 1.1 & -0.2 & -0.9 & -3.2 & -3.0 & -2.5 & -3.2 & -4.0 \\
\hline 2050 to 2070 & $2.6 \%$ & $-0.6 \%$ & $-1.3 \%$ & $-8.1 \%$ & $-8.5 \%$ & $-10.5 \%$ & $-5.8 \%$ & $-12.3 \%$ \\
\hline
\end{tabular}

models for the turnover of organic carbon in soil. Global Change Biology 11(1):154-66.

Kaurin,A., R. Mihelič, D. Kastelec, M. Schloter, M. Suhadolc, and H. Grčman. 2015. Consequences of minimum soil tillage on abiotic soil properties and composition of microbial communities in a shallow Cambisol originated from fluvioglacial deposits. Biology and Fertility of Soils 51(8):923-33.

Kibblewhite, M.G., B.J. Chambers, and K.W.T. Goulding. 2016. How good is the evidence to support investment in soil protection? Soil Use and Management 32:172-82.

Keiluweit, M., J.J. Bougoure, P.S. Nico, J. Pett-Ridge, P.K. Weber, and M. Kleber. 2015. Mineral protection of soil carbon counteracted by root exudates. Nature Climate Change 5(6):588-95.

Kirschbaum, M.U.F. 1995. The temperature dependence of soil organic matter decomposition, and the effect of global warming on soil organic C storage. Soil Biology and Biochemistry 27(6):753-60.

Kladivko, E.J., M.J. Helmers, L.J. Abendroth, D. Herzmann, R. Lal, M. Castellano, D.S. Mueller, J.E. Sawyer, R.P. Anex, R.W.Arritt, B. Basso, J.V. Bonta, L. Bowling, R.M. Cruse, N.R. Fausey, J. Frankenberger, P. Gassman, A.J. Gassmann, C.L. Kling, A. Kravchenko, J.G. Lauer, F.E. Miguez, E.D.
Nafziger, N. Nkongolo, M. O'Neal, L.B. Owens, P. Owens, P.Scharf, M.J.Shipitalo,J.S. Strock, and M.B.Villamil. 2014. Standardized research protocols enable transdisciplinary research of climate variation impacts in corn production systems. Journal of Soil and Water Conservation, Special Issue for Climate and Agriculture 69(6):532-542, http:// dx.doi.org/10.2489/jswc.69.6.532.

Lal, R. 2004a. Soil carbon sequestration to mitigate climate change. Geoderma 123(1-2):1-22.

Lal, R. 2004b.Soil carbon sequestration impacts on global climate change and food security. Science 304(5677):1623-27.

Lal, R. 2010. Managing soils and ecosystems for mitigating anthropogenic carbon emissions and advancing global food security. BioScience 60(9):708-21.

Lal, R. 2016. Beyond COP 21: Potential and challenges of the " 4 per Thousand" initiative. Journal of Soil and Water Conservation 71(1):20A-25A, doi:10.2489/jswc.71.1.20A.

Lal, R., J.A. Delgado, P.M. Groffman, N. Millar, C. Dell, and A. Rotz. 2011. Management to mitigate and adapt to climate change. Journal of Soil and Water Conservation 66(4):276-85, doi:10.2489/jswc.66.4.276.

Le Quéré, C., R. Moriarty, R.M. Andrew, J.G. Canadell, S. Sitch, J.I. Korsbakken, P. Friedlingstein, G.P. Peters, R.J. Andres, T.A. Boden, R.A. Houghton, J.I. House, R.F.
Keeling, P. Tans, A. Arneth, D.C.E. Bakker, L. Barbero , L. Bopp, J. Chang, F. Chevallier, L.P. Chini, P. Ciais, M. Fader, R. Feely, T. Gkritzalis, I. Harris, J. Hauck, T. Ilyina, A.K.Jain, E. Kato,V. Kitidis, K. Klein Goldewijk, C. Koven, P. Landschützer, S.K. Lauvset, N. Lefevre, A. Lenton, I.D. Lima, N. Metzl, F. Millero, D.R. Munro, A. Murata, JEMS Nabel, S. Nakaoka,Y. Nojiri, K. O'Brien,A. Olsen, T. Ono, F.F. Pérez, B. Pfeil, D. Pierrot, B. Poulter, G. Rehder, C. Rödenbeck, S. Saito, U. Schuster,J. Schwinger, R. Séférian, T. Steinhoff, B.D. Stocker, A.J. Sutton, T. Takahashi, B. Tilbrook, I.T. van der Laan-Luijkx, G.R. van der Werf, S. van Heuven, D. Vandemark, N. Viovy, A. Wiltshire, S. Zaehle, and N. Zeng. 2015. Global carbon budget 2015. Earth System Science Data 7:349-396.

Leakey, A.D.B, M. Uribelarrea, E.A.Ainsworth, S.L. Naidu, A. Rogers, D.R. Ort, and S.P. Long. 2006. Photosynthesis, productivity, and yield of maize are not affected by open-air elevation of $\mathrm{CO}_{2}$ concentration in the absence of drought. Plant Physiology 140(2):779-90.

Lee, J., J.W. Hopmans, D.E. Rolston, S.G. Baer, and J. Six. 2009. Determining soil carbon stock changes: Simple bulk density corrections fail. Agriculture, Ecosystems and Environment 134(3-4):251-56. 
Littlefield, B.Z., J.L. Ehman, W. Fan, J.J. Johnston, B. Offerle, and J.C. Randolph. 1998. Climate Change Effects on Agricultural Productivity in the Midwestern Great Lakes Region, eds. S.A. El Swaify and D.S. Yakowitz. Boca Raton, FL: Lewis Publishers Inc.

Lu, X., and Q. Zhuang. 2010. Evaluating climate impacts on carbon balance of the terrestrial ecosystems in the midwest of the United States with a process-based ecosystem model. Mitigation and Adaptation Strategies for Global Change 15(5):467-87.

Makipaa, R., M. Hakkinen, P. Muukkonen, and M. Peltoniemi. 2008. The costs of monitoring changes in forest soil carbon stocks. Boreal Environment Research 13:120-30.

Mangalassery, S., S. Sjoegersten, D.L. Sparkes, and S.J. Mooney. 2015. Examining the potential for climate change mitigation from zero tillage. Journal of Agricultural Science 153(7):1151-73.

Mearns, L.O., S. McGinnis, S. Biner, D. Caya, and R. Laprise. 2007. The North American Regional Climate Change Assessment Program (NARCCAP) dataset, National Center for Atmospheric Research Earth System Grid data portal. Boulder, CO: Earth System Grid at NCAR.

Mearns, L.O., S. Sain, L.R. Leung, M.S. Bukovsky, S. McGinnis, S. Biner, D. Caya, R.W. Arritt, W. Gutowski, E. Takle, M. Snyder, R.G. Jones, A.M.B. Nunes, S. Tucker, D. Herzmann, L. McDaniel, and L. Sloan. 2013. Climate Change Projections of the North American Regional Climate Change Assessment Program (NARCCAP). Climatic Change 120(4):965-75.

Melillo, J.M., T.C. Richmond, and G.W. Yohe, eds. 2014. Climate Change Impacts in the United States: The Third National Climate Assessment. U.S. Global Change Research Program, 841. Washington, DC: US Government Printing Office.

Menne, M.J., I. Durre, B. Korzeniewski, S. McNeal, K. Thomas, X. Yin, S. Anthony, R. Ray, R.S. Vose, B.E. Gleason, and T.G. Houston. 2012a. Global Historical Climatology Network-Daily (GHCN-Daily), Version 3. Annual Summaries of the Global Historical Climatology Network-Daily. NOAA National Climatic Data Center. October 8, 2015.

Menne, M.J., I. Durre, R.S. Vose, B.E. Gleason, and T.G. Houston. 2012b. An Overview of the Global Historical Climatology Network-Daily Database. Journal of Atmospheric and Oceanic Technology 29:897-910.

Mishra, U., R. Lal, D. Liu, and M. Van Meirvenne. 2010. Predicting the spatial variation of the soil organic carbon pool at a regional scale. Soil Science Society of America Journal 74(3):906.

Moran, K.K., and J.D. Jastrow. 2010. Elevated carbon dioxide does not offset loss of soil carbon from a corn-soybean agroecosystem. Environmental Pollution, Facing the Future: Evidence from Joint AspenFACE, SoyFACE and SFB 607 Meeting 158(4):1088-94.

NARCCAP (North American Regional Climate Change Assessment Program). 2016a. NCEP Seasonal Climate.
NARCCAP. http://www.narccap.ucar.edu/results/ ncep-results.html.

NARCCAP. 2016b. The A2 Emissions Scenario. North American Regional Climate Change Assessment Program (NARCCAP). http://www.narccap.ucar.edu/ about/emissions.html.

NARCCAP. 2016c. Atmosphere-Ocean General Circulation Models (AOGCMs). North American Regional Climate Change Assessment Program (NARCCAP). http://www.narccap.ucar.edu/about/aogcms.html.

NARCCAP. 2016d. Scatter Plots. North American Regional Climate Change Assessment Program (NARCCAP). http://narccap.ucar.edu/results/scatter/index.html.

Osanai, Y., J.K. Janes, P.C.D. Newton, and M.J. Hovenden. 2015. Warming and elevated $\mathrm{CO}_{2}$ combine to increase microbial mineralisation of soil organic matter. Soil Biology and Biochemistry 85:110-18.

Pan, Z., D. Andrade, M. Segal, J. Wimberley, N. McKinney, and E. Takle. 2010. Uncertainty in future soil carbon trends at a central U.S. site under an ensemble of GCM scenario climates. Ecological Modelling 221(5):876-81.

Panagopoulos, Y., P.W. Gassman, R.W. Arritt, D.E. Herzmann, T.D. Campbell,A.Valcu, M.K.Jha, C.L. Kling, R. Srinivasan, M.White, and J.G.Arnold. 2015. Impacts of climate change on hydrology, water quality and crop productivity in the Ohio-Tennessee River Basin. International Journal of Agricultural and Biological Engineering 8(3):1-18.

Paustian, K., J. Lehmann, S. Ogle, D. Reay, G.P. Robertson, and P. Smith. 2016. Climate-smart soils. Nature 532(7597):49-57.

Pereira, P., E. Isadora, H. Chung, K. Scow, and J. Six. 2013. Microbial communities and soil structure are affected by reduced precipitation, but not by elevated carbon dioxide. Soil Science Society of America Journal $77(2): 482$.

Powlson, D.S., C.M. Stirling, M.L. Jat, B.G. Gerard, C.A. Palm, P.A. Sanchez, and K.G. Cassman. 2014. Limited potential of no-till agriculture for climate change mitigation. Nature Climate Change 4(8):678-83.

Pryor, S.C., D. Scavia, C. Downer, M. Gaden, L. Iverson, R. Nordstrom, J. Patz, and G.P. Robertson. 2014. Chapter 18: Midwest. In Climate Change Impacts in the United States: The Third National Climate Assessment, eds. J.M. Melillo, T.C. Richmond, and G.W. Yohe, U.S. Global Change Research Program, 418-440.

Reeves, D.W. 1997. The role of soil organic matter in maintaining soil quality in continuous cropping systems. Soil and Tillage Research 43(1-2):131-67.

Saxton, K.E., and W.J. Rawls. 2006. Soil water characteristic estimates by texture and organic matter for hydrologic solutions. Soil Science Society of America Journal 70(5):1569-78.

Southworth, J., R. Pfeifer, M. Habeck, J. Randolph, O. Doering, and D. Rao. 2002. Sensitivity of winter wheat yields in the midwestern United States to future changes in climate, climate variability, and $\mathrm{CO}_{2}$ fertilization. Climate Research 22:73-86.
Thornthwaite, C.W., and J.R. Mather. 1955. The Water Balance. Publications in Climatology, Vol 8, No. 1. Centerton, NJ: Laboratory of Climatology.

Uri, N.D. 2001. The potential impact of conservation practices in US agriculture on global climate change. Journal of Sustainable Agriculture 18(1):109-31.

USDA NRCS (Natural Resources Conservation Service). 2005. Major Land Resource Area (MLRA) Definitions. http://www.nrcs.usda.gov/wps/portal/nrcs/detail/ soils/survey/geo/?cid=nrcs142p2_053625.

USDA NRCS. 2006a. Land Resource Regions and Major Land Resource Areas of the United States, the Caribbean, and the Pacific Basin: L - Lake State Fruit, Truck Crop, and Dairy Region; 99 - Erie-Huron Lake Plain. Major Land Resource Regions Custom Report, 2006. http://apps.cei.psu.edu/mlra/.

USDA NRCS. 2006b. Land Resource Regions and Major Land Resource Areas of the United States, the Caribbean, and the Pacific Basin: R - Northeastern Forage and Forest Region 139 - Lake Erie Glaciated Plateau. Major Land Resource Regions Custom Report, 2006. http://apps.cei.psu.edu/mlra/.

USDA NRCS. 2016. Soil Texture Calculator, NRCS Soils. Washington, DC: USDA National Resources Conservation Service. http://www.nrcs.usda.gov/wps/ portal/nrcs/detail/soils/survey/?cid=nrcs142p2_054167.

VandenBygaart,A.J. 2016. The myth that no-till can mitigate global climate change. Agriculture, Ecosystems and Environment 216:98-99.

van Groenigen, K.J., J. Six, B.A. Hungate, M. de Graaff, N. van Breemen, and C. van Kessel. 2006. Element interactions limit soil carbon storage. Proceedings of the National Academy of Sciences 103(17):6571-74.

van Groenigen, K.J., X. Qi, C. Osenberg,Y. Luo, and B. Hungate. 2014. Faster decomposition under increased atmospheric $\mathrm{CO}_{2}$ limits soil carbon storage. Science 344:508-9.

Walsh, J., D. Wuebbles, K. Hayhoe, J. Kossin, K. Kunkel, G. Stephens, P. Thorne, R. Vose, M. Wehner, J. Willis, D. Anderson, S. Doney, R. Feely, P. Hennon, V. Kharin, T. Knutson, F. Landerer, T. Lenton, J. Kennedy, and R. Somerville. 2014. Chapter 2: Our Changing Climate. In Climate Change Impacts in the United States: The Third National Climate Assessment, eds. J.M. Melillo, T.C. Richmond, and G.W. Yohe, U.S. Global Change Research Program, 19-67.

Williams, J., R.E. Prebble, W.T. Williams, and C.T. Hignett. 1983. The influence of texture, structure and clay mineralogy on the soil moisture characteristic. Australian Journal of Soil Research 21(1):15.

Xie, H., K. Liu, D. Sun, Z. Wang, X. Lu, and K. He. 2015. A field experiment with elevated atmospheric $\mathrm{CO}_{2}-$ mediated changes to $\mathrm{C} 4$ crop-herbivore interactions. Scientific Reports 5:13923.

Zong, Y., and Z. Shangguan. 2014. Nitrogen deficiency limited the improvement of photosynthesis in maize by elevated $\mathrm{CO}_{2}$ under drought. Journal of Integrative Agriculture 13(1):73-81. 